\title{
TORT LAW AND THE ALTERNATIVES: SOME ANGLO-AMERICAN COMPARISONS*
}

\author{
P.S. AtiYah $\dagger$
}

Most Americans seem to think that there is a huge and increasing volume of litigation in their country. Expressions of deep concern appear both in the scholarly literature ${ }^{1}$ and in the popular press. As Judge Aldisert of the Umited States Court of Appeals for the Third Circuit has written, "when people feel wronged by another person or institution, the immediate reaction is not to turn the other cheek, but to serve process and bring suit." "Americans in all walks of life," notes U.S. News \& World Report, "are being buried under an avalanche of lawsuits."3

This concern about the perceived overlitigious tendencies of Americans is also felt outside the United States. For a variety of reasons, people and institutions in other countries feel threatened by what happens in America. They worry that litigiousness will spread beyond America and engulf the world. The British medical profession, for example, is almost paranoiac in its fear of current trends in American malpractice litigation. ${ }^{4}$ Foreign businesses, in particular insurers and reinsurers, feel especially threatened by American litigation trends. They point out with some justification that their busmess becomes exceedingly hazardous when legal liability rules constantly change without notice, so that premiums collected are no longer sufficient to cover damages that have to be paid. ${ }^{5}$ Change is especially unpredictable in America where, unlike in Europe, the rules of legal liability are usually a product of judicial rather

* A version of the Currie Lecture given at Duke University Law School on March 26, 1987.

$\dagger$ Professor of English Law, Oxford University.

1. See, e.g., Rosenberg, Contemporary Litigation in the United States, in Legal INSTITUTIONS TODAY: ENGLISH AND AMERICAN INSTITUTIONS COMPARED 152 (H. Jones ed. 1977) [hereinafter LEGAL INSTITUTIONS TODAY].

2. Aldisert, An American View of the Judicial Function, in Legal INSTITUTIONS TODAY, supra note 1, at 31, 56.

3. Pike, Why Everybody is Suing Everybody, U.S. News \& WoRLD ReP., Dec. 4, 1978, at 50, 50.

4. See, for example, C. Hawkins, Mishap OR MALPRACTICE? ch. 9 (1985), which-in a book designed for a British audience-includes virtually a whole chapter on the American malpractice situation.

5. See, e.g., Fleet, Nader Charges Unfounded, The Times (London), Jan. 16, 1986, at 19, col. 1 (reporting that Lloyd's of London has "lost all condidence [sic] in the US system of tort law," even though British insurers still often offer Americans coverage that American insurers themselves are unwilling to provide). 
than legislative pronouncements and are therefore made without, or with less, advance notice. ${ }^{6}$ Still, foreign insurers who do business in the United States must, no doubt, expect to put up with American ways. This, of course, is also true of nianufacturers who export goods to the United States, thereby exposing themselves to products liability suits over here.

Americans might spare a thought for foreigners affected by American hitigation habits in ways impossible for them to foresee or guard against. There is, for instance, the foreign manufacturer who does no business directly with the United States, but who sells his products to another nianufacturer in his own country, and does not discover (until he is served with a claim for damages in the American courts) that the buyer incorporated those products into a completed article sold in the United States. ${ }^{7}$ Even the humble European tourist who rents a car in America may discover only too late that his American insurance policy, unlike his insurance policy at home, offers only limited protection against liability. Unless he is particularly well informed about American practices, he may easily be caught unaware. Of course, the inupact of Ameri-. can practices on foreiguers is a two-way street. In recent years, foreiguers injured in their own countries have discovered that it may be preferable to sue in America, if an American defendant is available, and if the American courts are prepared to accept jurisdiction. ${ }^{8}$ An asymmetry results because American law is generally more proplaintiff than the

6. Even in England, however, legislative changes do not always give insurers adequate notice of change. See P. ATtYAH \& P. CANE, ATTYAH'S ACCIDENTS, COMPENSATION AND THE LAW 253 (4th ed. 1987) (sudden change in rules governing assessment of damages does not give insurers adequate warning when premiums calculated several years in advance). In this article I generally refer to "England" although many of the statistics and data relate to the whole of the United Kingdom, or (sometines) to Great Britain. Statistics and other data relating to England nearly always cover both England and Wales.

7. See Warner, CBI to Fight US Liability Ruling. The Times (London), Apr. 28, 1986, at 17, col. 2 (Confederation of British Industry prepares to fight against a California court ruling that threatens extention of "already excessive claims by the US authorities of jurisdiction over foreign companies."). This fear, of course, is yet to be fully realized. See Asahi Metal Indus. Co. v. Superior Court, 107 S. Ct. 1026 (1987) (holding unconstitutional assertion of personal jurisdiction over Japanese tire valve manufacturer, whose products eventually entered American market after being incorporated in Taiwanese inner tubes).

8. A recent and especially well-publicized example of this sort of international forum shopping involved the Union Carbide chennical disaster at Bhopal, India in December 1984. Following the accident, nearly 150 tort suits were filed in American courts by Indian citizens. After consolidation of these actions by the Judicial Panel on Multidistrict Litigation, see In re Union Carbide Corp. Gas Plant Disaster, 601 F. Supp. 1035 (J.P.M.D.L. 1985) (per curiam), the case was assigned to the United States District Court for the Southern District of New York. The consolidated action was then dismissed on forum non conveniens grounds in favor of the Indian forum. See In re Union Carbide Corp. Gas Plant Disaster, 634 F. Supp. 842 (S.D.N.Y. 1986), aff'd in part and modified in part. 809 F.2d 195 (2d Cir. 1987). 
laws of other countries. Foreigners will sue in American courts much more frequently than Americans will sue in foreign courts; even though American lawyers inay benefit from the importation of foreign lawsuits, American insurers and American premium payers carry the burden of paying damages awarded foreigners in these lawsuits. This net deficiency in the American balance of trade may, I am afraid, be seen by some of my coinpatriots as the well-deserved penalty Americans inust pay for their litigiousness.

Because American litigiousness affects the whole world, and not just Americans, it is a particularly suitable topic for comparative study. Foreigners can therefore be forgiven for taking a particular interest when a distinguished American academic, Professor Marc Galanter of the University of Wisconsin Law School, labels the American hitigation explosion a inyth. ${ }^{9}$ America is, he says, no more hitigious than it has ever been, and even more strikingly, it is no more hitigious than many other countries. America is not, he says, "faced with an inexorable exponential explosion of cases, but with a series of local changes, soine sudden, but most incremental, as particular kinds of troubles nove in and out of the ambit of the courts."10 Even if there is a lot of hitigation, his comforting message goes on, we inust remember that it brings benefits as well as costs to a society. ${ }^{11}$ Until there is evidence to suggest that the costs outweigh the benefits, there is obviously nothing to worry about.

\section{The Volume of Tort Litigation}

I want to first exainine one relatively narrow question: the coinparative volume of tort litigation and tort claims in England and the United States. Professor Galanter's writings discuss hitigation in general and involve comparisons over time as well as coinparisons among other countries. ${ }^{12}$ So it is hardly surprising that he was unable to look at the fairly narrow question I want to look at in the saine depth and with the sanie range of data. ${ }^{13}$ On the other hand, the coniparison of tort rates in these two countries inay be of greater interest, even to Americans, than soine of the broader coinparisons niade by Galanter. First, England is still

9. See Galanter, The Day After the Litigation Explosion, 46 MD. L. REv. 3 (1986).

10. Id. at 38.

11. Id. at 28-37.

12. See, e.g., Galanter, Reading the Landscape of Disputes: What We Know and Don't Know (and Think We Know) About Our Allegedly Contentious and Litigious Society, 31 UCLA L. Rev. 4, 36-61 (1983).

13. I must, however, disclaim any hope of matching Galanter's detailed statistics. One major difference between English and American legal studies is the relative paucity of research facilities available to the English law professor. Although this article contains some statistics, they are mostly rudimentary or based on very rough calculations and estimates. 
thought to share much of American legal culture and legal ideals, even if, to paraphrase George Bernard Shaw, England and America sometimes appear to be two countries divided by a common legal heritage. ${ }^{14}$ Comparisons between these two countries should at least enable us to reduce the number of variables explaining the differences. Second, the focus on tort law is surely justified by the nature of tort litigation and the role it plays in society. Complaints about the volume of hitigation in America appear to focus on the volume of tort claims. No doubt there are other types of suits which could appropriately be classified with tort claims; however, it is quite clear that anxieties about the volume of hitigation are not directed to claims for many other kinds of legal redress, such as, for exainple, divorce suits, landlord/tenant disputes or claims for the simple payment of debts. ${ }^{15}$

Anxieties about tort litigation are surely of a different sort. No doubt these anxieties are compounded by, among other things, the difficulties of adjudicating and settling tort claims as compared, for instance, with adjudicatimg simple claims for debts. Although this undoubtedly increases the number of tort claims tried, the great mass of them are settled. ${ }^{16}$ Anxiety about the volume of tort litigation stems as well from worries that the legal system itself may be encouraging litigation which would not otherwise arise, or which would be channelled into less confrontational fora. Furthermore, it seems highly probable-though I cannot demonstrate it-that anxieties over the volume of litigation are also related to the sometimes astrono1mical damages paid in tort cases. There

14. Shaw is often said to have remarked that "England and America are two countries separated by the same language." See H. Prochnow \& H. Prochnow, JR., A Treasury of HumOrous Quotations 129 (1969).

15. Of course, a sudden surge in claims of these kinds might also be a cause for concern. Rising divorce rates, to be sure, worry many people, but for reasons having less to do with their burden on the courts. Similarly, a surge in claims for debts might suggest that in a time of high unemployment, too many people are simply unable to keep afloat. But simple debt claims present few problems to the legal system. I do not presume to speak of the American position, but in England at least, it is well known that enormous numbers of suits are filed for simple debts, to which no defense is ever made, and which usually lead to rapid payment or to a judgment by default. These claims take up the time of court admimistrative staff, but the overwhelmmg mass of them take no judicial time and involve no hearing, and therefore play almost no part in clogging up the courts. It seems very unlikely that complaints about the rising volume of litigation have any relation to increases in the number of claims for debts.

16. It has been estimated that only $9 \%$ of all American civil cases go to trial. See 2 O. Trubeck, J. Grossman, W. Felstiner, H. Kritzer \& A. Sarat, Civil Litigation Research Project: Final Report 56 (1983). In England, it seems that the trial rate is closer to $1 \%$ of total claims. See 2 Report of the Royal Commission on Civil Liability and Personal INJURY, 1978, CMND. No. 7054, at 19 table 11, 20 table 12 [hereinafter PEARSON REPORT] (estimating approximately 250,000 personal injury claims per annum; estimating that about $1 \%$ of claims reach trial). 
seems, therefore, good reason to look particularly at tort suits when examining the volume of litigation.

\section{A. Judges, Lawyers and Filings.}

Professor Galanter's comparison of litigation rates between the United States and various other countries is based on three sets of data: the number of judges per million of population, the number of lawyers per million of population, and the number of civil cases per thousand. ${ }^{17}$ The English figures are based on 1973 data; the American figures for judges and lawyers are based on 1980 data; the American filings statistics are current as of 1975 .

\section{TABLE 1}

\begin{tabular}{|c|c|c|c|}
\hline & $\begin{array}{l}\text { Judges per } \\
\text { million }\end{array}$ & $\begin{array}{c}\text { Lawyers per } \\
\text { million }\end{array}$ & $\begin{array}{c}\text { Filings per } \\
\text { thousand }\end{array}$ \\
\hline & 50.9 & 606.4 & 41.1 \\
\hline United & 94.9 & 2348.7 & 44.0 \\
\hline
\end{tabular}

Although the number of filings is not very different in the two countries, there are, according to Galanter's figures, almost twice as many judges, and nearly four times as many lawyers in America as in England. One's immediate reaction to these figures is to wonder what all the additional American judges and lawyers are doing if England can get through the same volume of litigation (proportionate to population) with half the number of judges and a quarter the number of lawyers as the Umited States! Part of the explanation, of course, is that many of these American lawyers and judges are engaged in criminal work, the volume of which is much greater in the United States than in England. Even with this factor in mind, however, many of Galanter's figures are of doubtful value.

Let us first examine the figures for the nuinbers of judges im the two countries. Galanter himself is the first to concede that these comparisons, even in relation to such an apparently straightforward question, are extremely treacherous. ${ }^{18}$ Many disputes are handled by tribunals of various kinds which are not courts, and before adjudicators who may or may not be judges. Only some of these bodies and adjudicators ought to be included in a comparison of the number of judges. Moreover, the purpose of the comparison may well determine on which side of the line we place them. For instance, when computing the comparative costs of a

17. Galanter, supra note 12 , at 52 table 3.

18. Id. at 51 ("Local differences in recording practices, differences in the jurisdiction of courts and other tribunals, and differences in what is recorded as a case all add to differences in substantive law, making comparison of litigation across societies extremely treacherous."). 
legal systein, they may be appropriately included with judges. If, however, we are trying to ascertain the extent to which adversarial-type litigation lias been replaced by alternative dispute resolution procedures, nany of thein should clearly be excluded. ${ }^{19}$ Because I am primarily interested in determining how inany judges are involved in adversarial litigation, I have simply excluded all suclr adjudicators from consideration. ${ }^{20}$ The calculation is also complicated by the number of part-time judges and judges or inagistrates who have little or no civil jurisdiction. I have attempted a relatively crude estimate of the number of judges in England and Wales by simply leaving out of account tribunals and adjudicators. I estimate thiat in England in 1984 there were about 12 judges per million of population, ${ }^{21}$ as compared to Galanter's estimate of over 50 per million. It may be imsleading to coinpare this figure with Galanter's estimate of 94.9 judges per million in the United States, since the precise basis of his computation is not entirely clear, though his figures are said to be coinpiled froin state and federal totals.22 All I can say, therefore, is that Galanter's figures on the number of Englisl1 judges ${ }^{23}$ appear entirely too high.

19. For example, workers' compensation disputes in England were dealt with by courts until 1948, when workers' compensation claims were absorbed by the social security, or "National Insurance" system, and channeled into the new National Insurance Appeal Tribunals. See National Insurance (Industrial Injuries) Act, $9 \& 10 \mathrm{Geo}$., ch. 62 (1946), now replaced by the Social Security Act, ch. $14, \S \S 50-78$ (1975). One of the main purposes of this change was to remove workers' compensation claims from the adversarial (tort-like) procedures of the courts. See generally P. ATTYAH \& P. CANE, supra note 6, at 313-26. Thus, it would be odd to imclude these tribunal members in a list of judges when one assesses the volume of tort hitigation in England.

20. I have also left out of account magistrates, who handle a huge volume of minor criminal work in England, but have very hittle civil jurisdiction except in simple matrimonial and other family cases, and certainly none in tort cases.

21. This estimate was computed as follows: in 1985, there were 76 High Court Judges, 371 Circuit Judges, 507 Recorders and 485 Assistant Recorders. 16 CENTral Statistical OfFice, Social TRENDS 202 table 12.34 (1987) [hereinafter Social TRENDS]. Rccorders and Assistant Recorders, however, are only part-time judges. Social Trends shows that High Court Judges sat for 13,000 days in 1985, Recorders for 12,500 days and Assistant Recorders for 12,250 days. Id. at 202. It seems, therefore, that in terms of equivalent full-time trial judges, there are 599: 76 Recorders, 76 Assistant Recorders, 76 High Court Judges, and the 371 Circuit Judges mentioned above. Combined with the nation's 34 appellate judges, listed in the All England Law Reports, the total number of judges in England is 633 . The population of England and Wales in 1986 was approximately 49.8 million, see THE WORLD ALMANAC AND BOOK OF FACTS 729-30 (1987), which yields a figure of 12.7 judges per million.

22. Galanter, supra note 12 , at 52 table 3. I have difficulty understanding how Galanter arrived at these figures. The 1986-87 Book of the States records that there are something over 8000 state court judges, but even when federal judges are included, this still gives a total of below 40 judges per million of population. 26 COUNCIL OF STATE GOVERNMENTS, THE BOOK OF STATES 155-58 tables 4.1, 4.2 (1986).

23. These figures appear to be largely derived froin E. JOHNSON, JR., S. BLACK, A. DREW, W. Felstiner, E. Hansen \& G. Sabagh, A COMparative ANalysis of the Statistical DimenSIONS OF THE JUSTICE SySTEMS OF SEVEN INDUSTRIAL Democracies 2-39 table II, 2-43 table VI 
I turn next to the numbers of lawyers in the two countries, estimated by Galanter at 606.4 per million in England in 1973 and 2348.7 per million in the United States in 1980. Fortunately, it is inuch easier to find some accurate and up-to-date figures. In 1985 there were 5367 practicing barristers and 46,490 practicing solicitors in England, a total of 51,857,24 which for a population of just under 50 million gives us about 1037 lawyers per million of population. This estimate, inuch higher than $\mathrm{Ga}$ lanter's figure, is due to a large increase in the nuinber of Enghish lawyers since 1973. The American Bar Foundation Research Study estimated that in 1985 there were approximately 674,000 attorneys in the United States, ${ }^{25}$ or roughly 2808 lawyers per million Americans. ${ }^{26}$ So, today there are almost three times as many lawyers per head in the United States as in England.

These figures, however, tell us fairly little about the coinparative rates of tort litigation in England and the United States. I turn therefore to Galanter's third ineasure, the number or rate of filings in the two countries. As already indicated, the rate turns out to be surprisingly similar; some 41 filings per thousand in population in England and Wales, and some 44 per thousand in population in the United States. My own rough estimates confirm the English figure. Unfortunately, this figure reveals little about the relative levels of tort hitigation, or indeed, any other litigation in the two countries. Everything depends, of course, on how "litigation" is defined. It does not seein very useful simply to count those pieces of paper used to imitiate soine kind of process in a court. The overwhelming majority of filings in England-what are called "plaints" in the County Courts-are simple claims for debts for goods supplied or for work done. In 1984 there were over 1.3 million such clainis, ${ }^{27}$ of which over one million led to judgment by default, or acceptance of the claim. ${ }^{28}$ These cases involve no hearing, and judgments are obtained by what is in essence an administrative process. In a large number of other cases, the debtor pays the ainount claimed (plus costs)

(1977) (report to the National Institute for Law Enforcement and Criminal Justice). For present purposes, the figures of English judges in this report (which are now somewhat dated anyhow) appear unduly infiated by the inclusion of magistrates (as opposed to judges), who have very little civil jurisidiction and none at all in tort cases.

24. 17 Social. TRENDS, supro note 21 , at 202 table 12.34 .

25. B. Curran, The lawyer Statistical Report: A Statistical Profile of the U.S. LEGAL PROFESSION IN THE 1980S (1985).

26. This attomey per capita figure is based on an estimated United States population of 240 million. See infra note 33 .

27. Statistics Branch, Lord Chancellor's Department, Judicial Statistics ANNUAL REPORT 1984: ENGLAND AND WALES, 1985 CMND. No. 9599, at 77 table 7.3 [hereinafter Judicial STatistics].

28. Id. at 78 table 7.4. 
as soon as the plaint is served on him; that is the end of the case. It does not seein very helpful to call this "litigation." It certainly bears very hittle reseinblance to the classic paradigm of tort litigation, and is hardly the kind of legal process that stirs up the complaints, anxieties and even passions over the inuch discussed American "litigation explosion." I therefore see nothing in Professor Galanter's figures to rebut the cominon belief that American tort litigation volume greatly exceeds that of England.

\section{B. Aggregate Tort Claims and Costs.}

Let us see whether there is more useful information to be found in other sources. Although there is a good deal of information on hand, it is often unsatisfactory in form, and always raises great difficulties when used for coinparative purposes. It is, however, inore useful than coinparing the number of judges or lawyers and filing rates. Let us consider first what information is available about tort law im aggregate terms. The best sources of information are in a 1985 study of American tort litigation by the Rand Corporation's Institute for Civil Justice ${ }^{29}$ and the 1978 Pearson Royal Commission Report on tort hitigation in the Uinted Kingdoin. ${ }^{30}$ According to the Institute for Civil Justice, soine 911,000 tort lawsuits were filed in 1985 in federal and state courts of general jurisdiction; ${ }^{31}$ according to the Pearson Report, there were in 1973 an estimated 250,000 tort claims for personal injuries in the Umited Kingdoin. ${ }^{32}$ The population of the Umited States is roughly four times that of the United Kingdom, ${ }^{33}$ so it looks at first blush as if the two figures are almost exactly comparable. Unfortunately things are never that simple. The inain difficulty is that the American figure is of lawsuits, while the Umited Kingdoin figure is for all personal injury tort claims-whether or not a lawsuit was filed. There is no doubt that a large number of tort claims, especially personal injury clains, are inade and settled every year without suit being filed. Fortunately we have reasonably accurate and up-todate figures on lawsuits in England. In 1984, 60,030 tort lawsuits were

29. J. Kakalik \& N. Pace, Costs of Compensation Paid in ToRt Litigation (1986).

30. See 2 Pearson Report, supra note 16.

31. J. KAKaliK \& N. PACE, supra note 29, at 13.

32. 2 Pearson Report, supra note 16 , at 19 table 11.

33. The estimated (1986) population of the United Kingdom is approximately 56 million; the estimated (1986) population of the United States is approximately 240 million. See WorLD ALMANAC AND BooK OF FACTS, supra note 21, at 729, 732. The population of England and Wales (as opposed to the United Kingdon-which includes Scotland and Northern Ireland) is about 49.8 million. Id. at 729-30. 
filed in England. ${ }^{34}$ When compared with the Institute for Civil Justice's figure of 911,000 American tort suits per annum, and after adjusting for population differences, this suggests an American tort lawsuit rate of nearly four times that in England. ${ }^{35}$

Unfortunately, even these figures are of limited value. Despite the fact that complaints focus (for obvious reasons) on the annount of hitigation (and hence the volume of lawsuits), the truth is that in the area of tort law, the number of lawsuits actually filed is of hittle importance. Most of these suits will not reach trial, but simply represent documents filed in a courtroom while a settlement is negotiated. Large numbers of claims will be inade, and settlements negotiated even when no suit has been filed. Some lawyers regularly file suit and negotiate afterwards, others negotiate first and only file suit if the negotiations do not go well. It makes hittle practical difference which course is followed; it does, of course, profoundly affect the number of recorded lawsuits. Thus, it is really more important to have figures on the total number of tort claims made, rather than suits filed, though one might also be interested in figures of cases actually reaching trial and judgment. In the absence of information on the relative ratios of suits filed to claims made, it is simply not possible to say how the numbers of tort claims compare in aggregate terms. While im England it seems that no more than one personal injury claim im five lead to the filing of a lawsuit, ${ }^{36}$ the American data suggest that a much larger proportion of claims lead to lawsuits-probably one in three in automobile cases, and perhaps as many as nine out of ten in inalpractice cases. ${ }^{37}$ This means that the estimated 911,000 filed lawsuits in America probably represent at least two million tort claims. 38

Unfortunately, there are no up-to-date English or Umited Kingdom figures fully comparable with the American tort litigation estinnates of

34. There were 31,470 personal injury suits filed (i.e., writs issued) in the High Court and 24,060 in the County Courts in 1984. In addition, there were 810 non-personal injury tort suits filed in the High Court and 3690 in the County Courts. These are figures for England and Wales. JUDICiAl Statistics, supra note 27, at 33 table 3.2, 77 table 7.3.

35. $60,030 \times \frac{240 \text { million }}{49.8 \text { million }}=289,301$, which is nearly one-third of the Institute for Civil Justice's figure of about 900,000 filings per annum. Note also that the English figure includes filings in courts of limited jurisdiction, while the American figure excludes such filings.

36. The Pearson Report estimated that roughly 250,000 claims per annun were made in England in 1973. See 2 PeArson RePort, supra note 16, at 19 table 11. According to inore recent (1984) statistics, 60,030 tort suits were filed annually in England. See supra note 34 and accoinpanying text. Even allowing for a very inodest increase in tort claims, the number of lawsuits filed today can scarcely be greater (and may be a lot less) than one in five clains.

37. See J. KAKALIK \& N. PACE, supra note 29 , at 31 (estimating that $33 \%$ of total coinpensation paid for auto accidents was paid in lawsuits, while $90 \%$ of medical malpractice payınents was paid in lawsuits).

38. Id. at 13 (1985 figures). 
the Institute for Civil Justice. The Pearson Report's estimate of the total value of tort payments and costs of administration in the Umited Kingdom in 1974 (but at 1977 prices) was $£ 377$ million. ${ }^{39}$ It is impossible to translate this into 1985 figures, because apart from inflation, nothing is really known about the volume changes of tort hitigation in either England or the United Kingdom since 1973. All that can be said is that, allowing for changes in the value of the British pound, total tort costs in the United Kingdom in 1985 would probably have been in the region of $£ 1$ billion, assuming no significant imcrease in the rates of claims or (in real terms) the levels of settlements.

Let me remind you that this United Kingdom estimate reflects the total cost of tort claims, and is not, like the American estimates of the Institute for Civil Justice, confined to the cost of tort lawsuits. To make any real comparison between these sets of figures, imprecise as they are, and qualified though they have to be, we must adjust the figures to reflect the difference between claims made and suits filed. As already noted, there is evidence that claims outnumber lawsuits by more than five to one in England, and by two or three to one in the United States. ${ }^{40}$ But we cannot simply multiply the dollar estimate for lawsuits by a factor of five, because it is almost certain that a disproportionate number of the larger claims lead to suits being filed. ${ }^{41}$ Fortunately, the Pearson Report contams data which enables us to make some comparison between the cost of claims and the cost of suits. From this data it is possible to calculate that in the United Kingdom im 1973 the total cost of claims was more than two and one half times the cost of suits filed, ${ }^{42}$ though $I$ have no way of knowing if the American proportion is comparable. At least this calculation enables one to reduce the estimate of the United Kingdom figures for total tort costs from $£ 1$ billion (for all tort claims) to something in the region of $£ 400$ million (for tort suits).

39. 2 PEARSON REPORT, supra note 16 , at 207 table 158. This figure is based on an estimate of $\mathfrak{f 2 0 2}$ million as total damages paid in personal injury cases in the United Kingdom, see 1 id. at 13 table 4 , and $£ 175$ million as the cost of admimistering the whole system, including defendant and insurers' costs, see 2 id. at 207 table 158.

40. See supra note 36 and accompanying text (English figures); note 37 and accompanying text (American figures).

41. It is possible to compute from the Pearson Report data that settlements in cases when suit was filed were on average 3.85 times larger than settlements when no suit was filed. 2 PEARSON REPORT, supra note 16, at 155 table 104. For American data, see A. CONRAD, J. MORGAN, R. Pratt, Jr., C. Voltz \& R. Bombaugh, Automobile ACcident Costs and Payments 182 table 6-1 (1964) (showing higher settlement rates in Michigan survey after suits filed).

42. The Pearson Report shows average payments when no suit was filed is $£ 400$ and average payment when suit was filed can be computed at $£ 1543$. 2 PEARSON REPORT, supra note 16, at 155 table 104. From these figures it is possible to calculate total costs of claims in this sample of cases at $£ 4.634$ million, while the total cost of cases in which suit was filed was $£ 1.787$ million. 
Thus, with all sorts of qualifications, the annual aggregate cost of tort suits in the United Kingdom may be in the order of $£ 400$ million, or at early 1988 exchange rates, about $\$ 707$ million, while the estimate of the Institute for Civil Justice of the total cost of tort suits in the United States was between $\$ 29$ and $\$ 36$ billion. Adjust by a factor of four (to reflect population differences) and we are still left with a staggering disparity, which I hesitate even to attempt to quantify because my figures are so rough, but which suggests that American tort costs are at least ten times higher per capita than those of the United Kingdom. This is as far as calculation can take us on the data presently available, and even then all sorts of qualifications still need to be made. First, the Institute for Civil Justice estimates relate to tort claims, while the Pearson Report figures refer only to personal injury clains, and take no acconnt of property dannage claims. I do not thmk this fact alone would make a huge difference to the figures because, surprising as it may seem, property dainage litigation in England is relatively rare compared with personal injury litigation, except in automobile accident cases. Second, it must be reinembered that a large part of tort damages in personal injury cases is desigued to replace lost income, and to meet out-of-pocket costs. Insofar as incomes and costs are significantly higher in the Umited States than im England, tort payments would naturally be higher. This is im itself no evidence of a greater use of tort law. Third, while it is relatively easy to adjust for population differences, it also has to be remembered that the number of tort suits and claims must bear some relation to the number of torts committed; adjustment for that purpose is almost impossible. ${ }^{43}$

\section{Data for Particular Kinds of Tort Claims.}

In addition to the aggregate data so far discussed, it is possible to find some figures dealing with particular kinds of tort claims and suits. If we could calculate what proportion of losses in the two countries are recovered in tort claims fiom various accidents, we could attempt to compile a comparative index revealing the degree to which tort claims are pursued. This would be a formidable task, which I lave neither the research facilities nor the expertise to seriously attempt, even confined to the United States and England. I have, however, attempted an extremely rough calculation of this kind with regard to road accident costs. A

43. It is possible to look at accident statistics as some sort of surrogate. The best available statistics are those for auto accidents, which show that the American fatality rate is more than eight times that of the British rate, or more than twice the British rate per million of population. Compare U.S. Dep't of COMmerce, Statistical Abstract of The United States 1987 table 1026 (45,700 deaths from auto accidents in 1985) with U.K. ANNUAL ABSTRACT OF STATISTICS FOR 1985 table 10.12 (5165 auto accident deaths). The disparity in injury rates is much smaller. 
United States Departnient of Transportion study on auto accident costs estimated that the total compensable economic losses in 1967 were about $\$ 10.5$ billion, ${ }^{44}$ and that about $\$ 3.5$ billion was paid out in tort recoveries. ${ }^{45}$ That is to say, auto victims recovered through tort claims about 30 percent of their losses. It was recently estimated in the United Kingdoni that the total cost of road accidents in Great Britain is about $£ 2.7$ billion, or roughly $\$ 4.8$ billion. ${ }^{46}$ The Pearson Report estimated that in 1973 about $£ 118$ million was paid out in conipensation for tort claims arising fron 1 road accidents. ${ }^{47}$ Adjusting crudely for inflation, and assuming no other changes, it seents that in 1984 roughly $\$ 413$ million (or $£ 236$ nillion) was paid for tort claims out of $\$ 4.7$ billion in total damages and costs: in otlier words, tort recovery provided conipensation for less than 9 percent of the total losses due to road accidents in the United Kingdoni. These are the roughest of estimiates, but at least they suggest that a niuch higher proportion of road accident losses are compensated through tort law in the United States than in England.

There is also sonie scanty information available on relative products liability clains in the two countries. In the United States, the Interagency Task Force Report estimated in 1976 that there were roughly 70,000 defective products law suits each year. ${ }^{48}$ The only information from the United Kingdom is the figure provided in the Pearson Report which, in 1973, estiniated the number of defective products tort claims at 1000 per year. ${ }^{49}$ Once agam, one niust renieniber that the United Kingdoin estimate is for all claims, and should be substantially reduced im order to conipare with actual lawsuits filed in the United States. Assun1ing the ratio of claims to suits is five to one in the United Kingdon1, ${ }^{50}$ there are approxinrately 200 annual United Kingdonı products liability lawsuits as conipared with roughly 70,000 annual products liability lawsuits in the United States. No niatter what adjustinents are niade for population and other variables, the conclusion is inescapable that the difference in the nuniber of products hability suits between the two countries is largely the result of cultural and environmental factors. It is

44. U.S. Dep'T OF TRANSP., MOtor VehicLE CRASH LOSSES AND THEIR COMPENSATION IN THE UNited States 6 table 2 (1971) (report to Congress and the President).

45. Id. at $\mathbf{4 8}$ table 20. This excludes medical expense paymeuts paid directly to health care providers, as well as claimants' attorney's fees.

46. 16 SOCIAL TRENDS, supra note 21, at 118 (1986) (1984 estimate).

47. 2 PEARSON REPORT, supra note 16, at 59 table 43, estimates that there were 98,300 tort payments in respect of road accidents in the United Kingdom in 1973, yielding an average payment of roughly $f 1200$. These figures were at 1977 prices; I have doubled them to reflect 1984 prices.

48. U.S. Dep'T of COMMERCE INTERAgency TASK Force on PRoduct Liability, Final REPORT I-3 (1978).

49. 2 PEARSON RePORT, supra note 16, at para. 228.

50. See supra note 36 and accompanying text. 
simply inconceivable that this huge difference is due to the number of injuries caused by defective products. We are therefore driven to the conclusion that Americans do indeed have either a greater urge or incentive than the Enghish to bring products hability tort suits. ${ }^{51}$

The story is much the saine with inedical malpractice. In 1983, for example, the United States saw some 40,000 inalpractice claims against physicians and surgeons; 52 this figure vastly exceeds the approximately 2000 annual claims processed by the medical defense societies in England. ${ }^{53}$ The figures on inedical malpractice premiums and payments reveal a great deal. Although premiums have doubled in the past two years in England, the standard premiuin as of 1987 was still only $£ 576^{54}$ (about $\$ 1018$ ), without any variation in premium rates according to medical speciality. ${ }^{55}$ The total amount paid out for malpractice claims by the medical defense societies in recent years has been in the region of $£ 15$ million, or roughly $\$ 26.5$ million per annum. ${ }^{56}$ Premiums of $\$ 50,000$ and even $\$ 100,000$ in the United States are not unknown. ${ }^{57}$ Medical inalpractice costs in America were estimiated in 1984 to be between $\$ 2$ billion to $\$ 4$ billion per year. ${ }^{58}$ Even after adjusting for population differences,

51. Furthermore, there is evidence (albeit not of very recent vintage) suggesting huge variations in the number of products liability suits brought in different parts of tle United States. See R. Keeton \& J. O'Connell, After Cars Crash 109 (1967).

52. 1 american Medical Ass'N, Special Task Force on Professional Liability, ProFESSIONAL LIABILITY IN THE '80S 10 (1984).

53. There are two medical defense societies currently operating in England (though botl also insure some doctors in the Commonwcalth): the Medical Defense Union (MDU) and the Medical Protection Society (MPS). The MPS lias about 100,000 inembers, the MDU rather more. These medical defense societies perform the same function as do medical liability insurers in the United States. See C. HAWkINS, supra note 4, at 17-57. The estimate of 2000 annual clains is derived from the Medical Protection Society, 1985 ANNUAL RePort AND ACCOUNTs No. 93, wlich sliows that the MPS handled 990 sucl claims in 1985. The other medical protection society, the MDU, probably handled a comparable number, though figures are not given in their annual reports.

54. Prentice, Huge rise in GPs' defence premiums, The Times (London), Aug. 19, 1986, at 3, col. 1 .

55. C. HAWKINS, supra note 4 , at 35 .

56. In 1984 , the MPS paid out $£ 6.5$ million ( $\$ 11.4$ inillion at the early 1988 exchange rate of $\$ 1.75$ per $\mathfrak{E}$ - the rate that is used throughout this article) for 990 claims (including tlose rejected). Medical Protection Society, supra note 53. The MDU paid out in 1983 (the last year for which figures are available) some $£ 8.3$ inillion (roughly $\$ 1.4 .5$ million) in damages and costs. Both figures include dental claims as well as some medical and dental claims from Ireland and the Coinmonwealtlı countries. The anounts paid out liave increased at a staggering rate. Only 20 years ago the total payments made were less than lialf a million pounds. See S. Cloopin, The Control of Medical Malpractice Through Legal Regulation 42 (1982) (unpublislied Oxford M. Litt. thesis).

57. See, e.g., Posner, Trends in Medical Malpractice Insurance, 1970-1985, 49 LAW \& CoNTEMP. ProBs., Spring 1986, at 37, 50 (Long Island, New York obstetricians paid $\$ 68,100$ for standard medical malpractice insurance in 1984. The preinium rose to over $\$ 100,000$ in 1985.).

58. See General Liability and Medical Malpractice Insurance Marketing, BEST'S REV., Sept. 1985 , at 108. The Institute for Civil Justice estimated that $\$ 1.5$ billion was paid to medical malpractice claimants by insurers in 1985. See J. KAKALIK \& N. PACE, supra note 29, at 141. The Institute 
the total cost of malpractice lawsuits in America is roughly thirty to forty times as great as it is in England. Of course, given the fact that individual recoveries are much higher in America, this does not inean that the number of claims or suits filed in America is thirty or forty times as great in England. But the size of aggregate tort payments is surely in itself a matter of interest and concern.

\section{Mass Tort Claims.}

Another aspect of modern tort law and tort litigation should also be mentioned: the mass tort claim. This is a relatively new phenomenon, restricted (thus far) mainly to the Umited States. These claims, as Professor Galanter has noted, are another cause of anxiety over the imcrease of tort hitigation in America. ${ }^{59}$ Although still relatively rare, these mass tort cases are often highly visible, much publicized events. They involve hundreds, and soinetimes thousands of plaintiffs, immense investigatory efforts, and usually complex issues of law and fact. After large numbers of prelimmary hearings and discovery skirmishes, they typically end in settlements whose chief beneficiaries seem to be attorneys rather than plaintiffs. ${ }^{60}$ Among the best known of the recent mass tort claims are those involving Agent Orange, ${ }^{61}$ the drug Bendectim, ${ }^{62}$ asbestos $^{63}$ and the Dalkon Shield. ${ }^{64}$ There is no doubt that these claims place an immense strain on the legal system; it has also been suggested that both costs and complexities increase exponentially with the number of parties, out of all

also estimated that "[t]he annual rate of growth in compensation paid from 1979 to 1985 averaged 25.0 percent." $I d$.

59. Galanter, supra note 9, at 24-26 (discussing increase of mass tort claims involving allegedly defective products, such as asbestos and the Dalkon Shield).

60. A number of these cases are reviewed in Sugarman, Doing Away with Tort Law, 73 CALIF. L. REv. 555, 596-603 (1985). Professor Sugarman noted the "[t]orts as a compensation mechanism is [both] highly uneven and terribly inefficient." Id. at 602. Litigation in the protracted and costly Dalkon Shield cases began in 1970; as of December 1984, only two-thirds of the roughly 11,200 clanns were settled. Id. at 601-02. 'By August 1984, [A.H.] Robins' [the producer of the Dalkon Shield] insurers had paid out $\$ 132$ million. Presumably, less than $\$ 100$ million went to the victims themselves. In addition, Robins had paid \$101 milhon in hitigation expenses." Id. at 602-03 (footnote omitted).

61. See In re "Agent Orange" Product Liability Litigation, 597 F. Supp. 740 (E.D.N.Y. 1984); see also Sugarman, supra note 60, at 597-98.

62. See In re Richardson-Merrell Inc. "Bendectm" Products Liability Litigation, 533 F. Supp. 489 (J.P.M.D.L. 1982). In re "Bendectin" Products Liability Litigation, 102 F.R.D. 239 (S.D. Ohio), vacated, 749 F.2d 300 (6th Cir. 1984); see also Sugarman, supra note 60, at 599-600.

63. See generally Sugarman, supra note 60 , at $600-01$ (suggesting that as of date of article, some 25,000 claims had becn brought against those in the asbestos industry).

64. See, e.g., Palmer v. A.H. Robins Co., 684 P.2d 187 (Colo. 1984); see also Sugarman, supra note 60 , at $601-03$. 
proportion to the size of their aggregate recoveries. ${ }^{65}$

Although quantitative comparisons between such tort claims in different countries is impossible, largely because of their scarcity outside the United States, these claims must be considered when assessing the overall volume of tort litigation. Such cases are almost completely unknown im England. Although English law does not allow class actions, ${ }^{66}$ it is occasionally possible to achieve a similar result by consolidatimg and then trying together a series of individual cases. An exceptionally high degree of cooperation among the lawyers for all parties is required for any worthwhile results to be achieved. A recent example of such a series of claims, Thompson v. Smiths Shiprepairers (North Shields) Ltd., 67 involved six individual plaintiffs and three different defendants. The case involved tort claims by a number of workers against their employers for negligently exposing them to the risk of industrial deafness. As the judge explained, the legal system was in danger of being swamped because of the large $(20,000)$ number of claims. ${ }^{68}$ A number of these cases were therefore selected, by cooperation of the lawyers and parties, differing as to the identity of the employers, the type of work, the length of exposure, the degree of deafness and so on. Much of the evidence was, of course, expert testimony common to all the cases. Although a series of cases of this kind obviously involves inuch preparation and time, it was possible for these cases to be heard fully by a single judge, with a decision handed down within six weeks of the conclusion of the hearing. There was no appeal, and no further proceedings lave been reported. Presumably most of the claims have now been settled with the assistance of this opinion. In terms of speed, efficiency and conservation of financial and legal resources, this case bears little resemblance to the mass tort claims that have troubled American lawyers for some years.

\section{Some Possible EXPlanations for the Differences}

If it is reasonably plain that the volume, and the total cost, of tort litigation and tort payments in the United States greatly exceed the comparable volume and costs in England, one must naturally ask why this is so. This leads to some pretty speculative inquiries. I shall start by men-

65. See Epstein, The Legal and Insurance Dynamics of Mass Tort Litigation, 13 J. LEGAL STUD. 475, 506 (1984).

66. See Markt \& Co., Ltd. v. Knight Steamship Co., Ltd., [1910] 2 K.B. 1021 (if only relief clained is dainages, other parties cannot have same interest as plaintiff so as to justify class action). For some modern questions about the contimued validity of this approach, see Tur, Litigation and the Consumer Interest; the Class Action and Beyond, 2 LEgaL STuD. 135, 154-55 (1982) (discussing recent cases holding representative plaintiff may bring suit for damages).

67. [1984] 1 Q.B. 405 (1983).

68. Id. at 409. 
tioning, only to put aside, three broad factors which partially explain the difference. I put them aside not because I do not believe they are important, but because their importance is difficult to assess, and, even if they do turn out to be verifiable, it is hard to see what can be done about them.

The first of these factors is the availability of the contingent fee arrangement in America, which means that an accident victim witl a reasonably plausible cause of action will normally have no problem in finding a lawyer to take his case. In England, contingent fees are considered unethical, ${ }^{69}$ but lawyers are not prohibited from arranging to liave their fees in personal injury cases paid from the recovery; indeed, this is a common arrangeinent. ${ }^{70}$ This is not regarded as violating the prohibition against the contingent fee; the lawyer is not permitted to waive all claims to payment in the event of no recovery, nor is lie permitted to accept a percentage of the recovery in lieu of a fee. These differences in fee practice may appear relatively umimportant, because the reality is that the accident victim with a reasonable case slould be able to find a lawyer witl equal ease in England and America. Nevertlieless, the differences appear to be very considerable, though it is not easy to explain exactly why. Any suggestion that the contingent fee enables American lawyers to take on speculative cases is usually criticized as unfounded, on the ground that no lawyer wants to take on work that is unlikely to bring in any reward. Perhaps the difference lies in the fact that personal injury litigation is actually highly profitable to lawyers in America, and that they do have an interest to take on and vigorously pursue sucli cases. In England, personal injury litigation is not generally regarded as highly profitable, and because of this many lawyers are uninterested in sucl work. If they do take on sucli cases, they inay be prone either to recommend settlement or abandoninent of the case long before an American attorney would take such a step. Possibly inore important than the differences themselves is public knowledge of the respective arrangements. I believe the contingent fee is a well understood arrangement in America, and probably few Americans are discouraged from applying to lawyers out of fear of the cost; in England, on the other hand, fear of legal costs does seem to be a factor that sometimes discourages accident victims from seeking legal assistance. ${ }^{71}$

69. See Solicitors Act, 1974, ch. 47, § 59(2)(b); see also In re Trepca Mines, Ltd. (No. 2), [1963] 1 Ch. 199, 219-20 (C.A. 1962) (agreement by lawyer to share damages contrary to public policy, not merely unprofessional).

70. P. ATIYAH \& P. CANE, supra uote 6, at 259.

71. See Harris, Claims for Damages: Negotiating, Settling or Abandoning, in CoMPENSATION AND SUPPORT FOR ILINESS AND INJURY 72 table 2.12 (D. Harris ed. 1984) [hereinafter COMPENSATION AND SUPPORT] (showing $11 \%$ of possible claimants deterred by fear of legal costs). 
The second factor arises from broad political and institutional differences between the United States and Britain. ${ }^{72}$ Britain is a country with powerful centralized political institutions, in which governments are expected to govern, and legislatures to legislate. Major social problems are expected to be addressed by these institutions. Individual decisionmaking, whether through the market or through decentralized judicial decisionmaking, does not play as large a role in Britam as it does in America. Indeed, I suspect that if Britam ever had as much tort litigation as does the United States, it would probably be regarded as an intolerable state of affairs, and would prompt the government and legislature to reduce the volume of hitigation and the level of compensation. In contrast, legislative and executive decisionmaking in America is traditionally more decentralized; judges and juries are the traditional sources for many of these decentralized decisions. It is thus no exaggeration to see American tort law as the major means for settimg norms and standards for social and economic behavior..$^{73}$ American tort law is a response to the demands of a society im which there are many grievances not regarded as the responsibility of governments to redress.

The third factor, about which I shall say very hittle, concerns the possible litigiousness of the American people. It is sometimes suggested that Americans are more aggressive, more hostile and less willing to put up with minor complaints and disturbances im their hives. As Professor Galanter has observed, it is not entirely clear whether the comparison implicitly drawn by such suggestions is with Americans as they once were, or with other peoples and countries today. ${ }^{74}$ So far as comparisons with Britain (and indeed many other countries) are concerned, the far higher levels of criminal violence in America may be evidence supporting this thesis. ${ }^{75}$ One of the great difficulties in trymg to isolate factors of this kind is that we do not know to what degree the law reflects, as opposed to creates, these public attitudes. Some modern research at the Centre for Social-Legal Studies at Oxford suggests that it is very danger-

72. See generally P. AtiYah \& R. SUmmers, Form and Substance in ANGlo-American LAW (1987).

73. See, e.g., Special Comm. on the Tort Liab. Sys., American Bar Ass'n, Towards a JuRisprudence of INJURY: The CONTINUING CREATION OF A SYSTEM OF SUBSTANTIVE JUSTICE IN AMERICAN TORT LAW 3-10 to 3-13, 3-21 to 3-29 (1984) [hereinafter TowARDS A JURISPRUDENCE OF INJURY] (discussing "[t]he moral thrust of tort law").

74. Galanter, supra note 9, at $11,36$.

75. For some basic data on the very different levels of criminal violence in New York City and London, see Hughes, English Criminal Justice: Is it Better Than Ours?, 26 ARIz. L. REv. 507, $809-$ 10 (1984) (using 1978 figures for London and 1980 figures for New York to formulate "a rough comparison suggest[ing] that London has an incidence of about 1.6 homicides per 100,000 people, while New York has 25.75; London has 4 rapes per 100,000, while New York has 53; London has 94 robberies per 100,000, while New York has 1429). 
ous to assume that tort law mirrors the public desire for vengeance or compensation against perceived inalefactors; ${ }^{76}$ on the contrary, this research suggests that except in very simple cases, accident victims tend to allocate blame after they have learned what the law requires for a claim to be made, and that their demands for compensation for injuries are frequently not directed against those who cause the injuries, but against those who can pay. ${ }^{77}$ Of course in England these matters are settled by judges and not juries; it may therefore be argued that American juries keep tort law more closely in accord with public sentiments. One problem with this thesis is the variability of American juries. We are, for example, told by experienced tort lawyers that the saine injury might lead to a tort award ranging "from $\$ 10,000$ to $\$ 2,000,000$ depending on the jurisdiction." 78 If juries are as variable in their views of what justice requires, it is difficult to feel confident that American tort law does, or even can, reflect sucl an extraordinary diversity of opmion. Perhaps even in America, current practice determines public ideas and sentiments as much as it reflects them; these are, indeed, difficult matters to assess.

It is, I think, possible to explain differences in the volume and cost of tort litigation between England and America without referring to the alleged litigiousness of the American people. Grievants, like most people, will respond to incentives and disincentives. It is true, as Professor Galanter suggests, that litigation is rarely simple and often emotionally traumatic, so a high volume of hitigation is unlikely to be the result of a casual and lighthearted desire to make someone's life uncomfortable. ${ }^{79}$ Other things being equal, one might expect grievants to pursue alternatives that produce comparable benefits at lower costs. But in fact other things are not equal. Tort law is much nore widely available in the Umited States than in England, simply because the law is inore favorable to plaintiffs. Here, therefore, is one major set of factors explaiming why the volume of tort litigation is so much lower in England. A second factor, I shall suggest, is that the incentive to litigate is much greater in America because the rewards are much higher. Even if the hassle and emotional strain of making a tort claim is as great im America as in England (and I think that it probably is not), the levels of damages in many American tort suits are now so great that they surely must be a major factor $\dot{m}$ explaining why so many more suits are brought. Third, I shall

76. See Lloyd-Bostock, Fault and Liability for Accidents: The Accident Victim's Perspective, in COMPENSATION AND SUPPORT, supra note 71, at 159-60.

77. Id. at 151 (citing survey evidence suggesting that "[ [] he attribution of fault is a justification rather than a motive for seeking damages" (emphasis in original)).

78. TOWARDS A JURISPRUDENCE OF INJURY, supra note 73, at 2-26.

79. Galanter, supra note 9, at 25-26, 30. 
suggest that there are more nonlitigious alternatives in England than in the United States.

These three factors may well sufficiently explain in large part the differences between England and America without having to postulate that Americans are inore aggressive, inore self-assertive and more hitigious than the English. Perhaps they are-these things are not easily proved, but of one thing II ain reasonably confident: if Enghish law and practices were replaced overnight by American law and practices, there would be a inassive increase in the volume of tort claims and suits in England.

\section{A. American Law is More Proplaintiff Than English Law.}

American and English tort doctrines increasingly have tended to drift apart, and although there may be a few corners of the law in which English law is actually inore proplaintiff than in some American jurisdictions, ${ }^{80}$ most of the differences tend to favor the plaintiff in America. ${ }^{81} \mathrm{I}$ shall pick out what seens to ine to be some of the inore important differences.

First, English tort law is still overwhelmingly fault-based, 82 while American tort law today contains inany inore examples of strict hability. It is difficult to assess the importance of this factor. Many American lawyers suggest that products hability cases are still difficult to win if there was no fault because juries do not like to rule against blameless

80. It must always be remembered, however, that it is uncertainty that engenders most trials and appeals. For instance, in one major respect English law tends to be more proplaintiff than American law: the liability insurance system relating to road accidents is more extensive in the United Kingdom, because it is conpulsory and because it also covers unlimited labilities. This tends to eliminate many forms of litigation common in the Umited States which occur as a result of the driver being uninsured or insured for an inadequate sum, thereby driving the plaintiff to sue other defendants, whose legal and factual responsibilities are more problematic. Other things being equal (which of course they are not), this would result in American law producing fewer tort payments but more claims and trials.

81. But there are exceptions. See, for example, McLoughlin v. O'Brian, [1983] I A.C. 410,418 (1982), in which the House of Lords followed the Supreme Court of California's deeision im Dillon v. Legg, $682 \mathrm{Cal} .2 \mathrm{~d} 728,441$ P.2d 912, 69 Cal. Rptr. 72 (1968), and allowed a cause of action for the negligent infliction of emotional distress. This, of course, is not the prevailing law in a majority of American states. See, e.g., McGovern v. Piccolo, 33 Conn. Supp. 225, 372 A.2d 989 (1976); Tobin v. Grossman, 24 N.Y.2d 609, 249 N.E.2d 419, 301 N.Y.S.2d 554 (1969); Whetham v. Bismarck Hospital, 197 N.W.2d 678 (N.D. 1972); Grimsby v. Samson, 85 Wash. 2d 52, 530 P.2d 291 (1975).

82. The one prominent exception to fault-based liability is the area of defamation, which remains a strict liability tort in England. See R. Heuston, SALmond on TorTs 135 (18th ed. 1981). Thus, it is easier to establish a defamation cause of action in Great Britain than in America, where constitutional doctrine now severely' restricts tort liability. See New York Times Co. v. Sullivan, 376 U.S. 254 (1964). On the other hancl, British defamation suits are notorious for their cost and procedural pitfalls, so the disincentives to litigate are very great, despite the apparent ease of establishing a cause of action. 
defendants. ${ }^{83}$ English law recognizes a form of strict products hability through sales warranty law, ${ }^{84}$ although this remedy fails to protect the nonbuyer-plaintiff and is available only against the seller-defendant. In practice, however, it probably covers the great majority of ordinary products liability claims. ${ }^{85}$ Perhaps of equal practical importance is the " $\mathrm{m}$ formed consent" doctrine recognized in many American jurisdictions. It effectively turns liability for intentional battery into something approximating (im soine cases) strict hability. ${ }^{86}$ England rejects this informed consent doctrime, insisting instead that the failure to warn of the risks attending medical or surgical procedures nust be tested against the usual fault standard apphicable to inedical neghigence. ${ }^{87}$

Second, the fact that most American tort actions are tried by a jury while English actions are tried by a judge may well mean that neghigence is more easily found in America than in England. Again, it is difficult to be sure about this. It would be wrong to inake the facile assumption that American juries, if given the chance, will always find for the plamtiff. But two important differences between an Enghish judge and an American jury make sympathy verdicts more likely in America. First, the American juror is sheltered by the anonymity of the collective decisionmaking process. Second, the Enghish judge must give reasons for his decisions, even on questions of fact. These reasons, often considerably detailed and often discussed at length in appellate opinions, are part of any important or complex decision. Unlike an American judge, who usually only has to decide whether evidence of neghigence is fit for the jury, an English judge must first decide whether there actually was neghgence, and then must justify his or her decision. This ineans that findings of neghigence not really warranted by the evidence are much less likely to occur in England. This is especially noticeable in professional liability cases, particularly in medical inalpractice cases, where Enghish judges appear to bend over backwards to avoid either second-guessing or condemning the judgnient of their fellow professionals. Indeed, Enghish judges are openly fearful of the American medical malpractice hitigation

83. See, e.g., 4 F. HARPER, F. JAMES \& O. GRAY, THE LAW OF TORTS $\$ 22.1$, at $270 \mathrm{n} .23$ (2d ed. 1986 \& Supp. 1987).

84. See P. ATIYAH, The SAlE of Goods $100-59$ (7th ed. 1985).

85. Id. at 160-66. The Consumer Protection Act, 1987, ch. 43, $\S \S 1-9$, will introduce some degree of strict liability for defective products when it comes into force, but the legislation unfortunately takes very little account of the American cxperience. See generally Stapleton, Products Liability Reform-Real or Illusory?, 6 OXFORD J. LEGAL STUD. 392 (1986) (criticizing reformers' adoption of defect-based, cost-benefit regime similar to that in the United States rather than a full strict liability approach).

86. See, e.g., Canterbury v. Spence, 464 F.2d 772, 780-92 (D.C. Cir.) (surveying informed consent law), cert. denied, 409 U.S. 1064 (1972).

87. See Sidaway v. Bethlem Royal Hospital, [1985] 1 A.C. 871. 
experience, and soinetimes comment on it in refusing to find English doctors guilty of negligence. ${ }^{88}$

Third, dainages for the death of a close relative, irrespective of financial dependency, are inore available in the United States than in England. In inost states, an action lies on behalf of either the estate or the designated beneficiaries of a person who has died as the result of a tort; full damages (even punitive dainages) are usually available. ${ }^{89}$ In England, on the otlier liand, unless the plaintiff can prove actual financial loss or financial dependence upon the deceased, wrongful death hability is very limited. Today, this limited hability is a statutorily fixed sum of $£ 3500$ (approximately $\$ 6125$ ) for the loss of a minor unmarried child or a spouse. 90 Because the amount is fixed by the statute, the death of small cliildren rarely gives rise today to litigation in England. Similarly, there is virtually no legal liability for the tort-related death of elderly retired people who have no financial dependents. Thus, a inajor source of tort liability and lawsuits in the United States simply does not exist in England. ${ }^{91}$

Fourth, levels of damages are far higher in America than in England. To a linited extent, this is exphicable by the prosaic fact that earnings and out-of-pocket losses will be higher in America tlian in England. But there are other reasons why damages are far higlier. Even with regard to earning losses, I think American juries are inuch inore generous than English judges in calculating the present value of future losses and

88. See, for example, Lord Denning's opinion in Whitehouse v. Jordan:

Take heed of what has happened in the United States. "Medical Inalpractice" cases there are very worrying, especially as they are tried by juries who have syinpathy for the patient and none for the doctor, who is insured. The damages are colossal. The doctors insure but the preniunus are very high: and these have to be passed on in fees to the patients. Experieneed practitioners are known to have refused to treat patients for fear of being accused of negligence. Young nen are even deterred from entering the profession because of the risks involved. In the interests of all, we must avoid such consequences in England.

[1980] 1 All E.R. 650, 658 (C.A. 1979). Although other judges are not as open as Lord Denning in acknowledging their fear of the American experience, it probably influenees their decisionmaking.

89. 4 F. HARPER, F. JAMES \& O. GRAY, supra note 83, § 24.2, at 459.

90. Adninistration of Justice Act, 1982, ch. 53, § 3. This section replaced some rather confused and coniplex law under which damages for "lost expectation of life" could be recovered on behalf of the estate of a person even if there was no financial dependency. See Fatal Accidents Act, $1976, \mathrm{ch} .30$. Such damages (which were in any event for very hinited amounts) were abolished by the 1982 Act. Id. § 1 .

91. When I was a visiting Professor at Duke Law School in the spring seinester of 1985, I was struck by newspaper reports of a case in Durham, North Carolina in which the parents of a sixteen year-old child recovered damages of \$3 million against the Duke Power Coinpany for alleged negigence in failing to lock an electric substation into which the deceased child had entered. See, e.g., Stevenson, Duke Power Suit Cash Pledged, Durham Morning Herald, Jan. 29, 1985, at 1, col. 3. I thought it unlikely that an Enghish judge (at least on the basis of these newspaper reports) would have found negligence in such a case. In any event, the parents could not have recovered in England nore than the statutory sum of $£ 3500$. 
in discounting contingencies. Because English judges are responsible for fixing (and justifying) the awards, and because their decisions are subject to appellate review, these figures are calculated in a fairly precise manner. ${ }^{92}$ There is a widespread belief, ${ }^{93}$ supported to soine extent by the Pearson Report, ${ }^{94}$ that Englisli judges, for all their experience, tend to systematically undervalue the present value of future earnings. In some American cases, detailed jury instructions are not given with regard to discounting the future loss to arrive at present value; ${ }^{95}$ even when sucli instructions are given, juries seexn to lave a good deal of latitude and often take a fairly generous view. Sone Americans argue that this is one way of offsetting the unfairness of not instructing the jury to take account of future inflation or legal fees. ${ }^{96}$ The Enghish courts, however, do not to take account of inflation because the plaintiff receives a lump sum whicl he can invest to protect himself against any future fall in the value of money. ${ }^{97}$

A much more important influence upon the size of damage awards is the extraordinarily high levels in America for pain and suffering, or loss of anemity as it is called in England. Because civil jury trials in the United States are constitutionally guaranteed, ${ }^{98}$ American judges can do hittle more tlian check wilder or more eccentric jury awards. On the other l1and, the English system leads to a high degree of internal consistency; it is possible to say tlrat today the inaximum award for pain and suffering in England is approaching $£ 100,000$ or about $\$ 175,000.99$ This, of course, is a great deal less than American juries award in cases of any gravity, where dainages of several million dollars are often given and uplreld. Althougl the huge disparities in American jury awards make systematic contrast with Englislı practice impossible, even average awards in American personal injury cases are substantially higher than those in

92. See, e.g., Mitchell v. Mulholland, [1971] A.C. 666 (1970); Taylor v. O'Connor, [1971] A.C. 115 (1970).

93. See, e.g., Prevett, Actuarial Assessment of Damages: The Thalidomide Case, 35 MoD. L. REv. 140, 257 (1972) (advocating use of actuarial methods in the assessinent of damages).

94. 1 PEARSON REPORT, supra note 16, paras. 675-691 (majority view); id. paras. 709-726 (minority view). See generally id. ch. 15 (discussing calculation of damages).

95. 4 F. HARPER, F. JAMES \& O. GRAY, supra note $83, \S 25.8$, at $553-54$ (discussing cases in which jurors allowed to use judgment based on available evidence in awarding damages to plaintiffs either with no source of income, or earnings demonstrably lower than earning capacity).

96. See, e.g., McWeeney v. New York, N.H. \& H. R.R., 282 F.2d 34, 37-38 (2d Cir.) (Friendly, J.), cert. denied, 364 U.S. 870 (1960).

97. See Cookson v. Knowles, [1979] A.C. 556, 576-77 (1978).

98. U.S. CONST. amend. VII.

99. Cf. Housecroft v. Burnett, [1986] 1 All E.R. 332, 340 (C.A. 1985) (establishing an average figure of $£ 75,000$ (roughly $\$ 131,250$ ) for a tetraplegic's pain and suffering and loss of amenities). 
England. ${ }^{100}$ As already noted, there are similar disparities between American and English awards in wrongful death cases.

On top of these differences in compensatory awards is the fact that punitive damages in tort cases are far inore available in the Uirited States than in England. There has been an explosive growth in punitive damage awards in recent years, particularly in the area of products liability. ${ }^{101}$ Although inany of the inore outlandish awards do not survive appeal, ${ }^{102}$ the appellate court's sense of a "tolerable" award often seems to depend on what juries typically do. Where juries habitually award punitive damages of $\$ 10$ million or more, appellate courts may reluctantly encroach on the decision of the jury by giving the plaintiff a choice between a retrial or a substantially reduced award of only one million dollars-not a trivial sum for damages, which by definition, goes beyond what is needed to fully compensate the plamtiff for lis injuries. ${ }^{103}$ In England, punitive damages are almost never allowed in ordinary personal mjury cases, ${ }^{104}$ including intentional tort cases, unless an unconstitutional action, such as wrongful arrest by police autliorities, is involved.

One other set of rules leads to higher damages in the United States than in England. The collateral benefit rule, more widely apphed in America, allows the plaintiff to pile benefit upon benefit. ${ }^{105}$ Although the

100. Compare 2 Pearson REPort, supra note 16, at 173 table 128 (median award of damages in court in England and Wales was $£ 1155$ in 1973 (1977 prices), equal perhaps to about $£ 3500$ today or approximately \$6125) with J. KAKALIK \& N. PACE, supra note 29, at 35 (average American tort lawsuit award between $\$ 24,000$ and $\$ 29,000$ in 1985). Note, however, that the English figure excludes "costs" which would be separately paid for by defendant, while the American figure imcludes the fee which plaintiff would have to pay his lawyers.

101. See generally 4 F. HARPER, F. JAMES \& O. GRAY, supra note 83, § 25.1, at 491 n.2, $\S 25.5 A$, at 526 \& n.2; Owen, Problems in Assessing Punitive Damages Against Manufacturers of Defective Products, 49 U. CHI. L. REV. 1, 1-5 (1982).

102. See Landes \& Posner, A Positive Economic Analysis of Products Liability, 14 J. LEGAL STUD. 535, 563-66 (1985).

103. Thus, although the jury's preposterous verdict for $\$ 125$ million in punitive damages in the Ford Pinto case was set aside on appeal, the plaintiff was still given the alternative of keeping $\$ 3.5$ million in punitive damages (on top of his compensatory award of $\$ 2.5$ million). See Grimshaw v. Ford Motor Co., 119 Cal. App. 3d 757, 174 Cal. Rptr. 348 (1981). The sum of $\$ 125$ million (m 1981) can be contrasted with the estimated total of personal injury tort hability payments in the United Kingdom (in 1974) of £202 nillion. See 2 PEARSON REPORT, supra note 16, at 207 table 138.

104. See Holden v. Chief Constable of Lancashire, [1987] 1 Q.B. 380 (C.A. 1985); Broome v. Cassell \& Co., Ltd., [1972] A.C. 1027; Rookes v. Barnard, [1964] A.C. 1129.

105. See generally 4 F. HARPER, F. JAMES \& O. GRAY, supra note $83, \S 25.22$, at 648-50 ("[T] he plaintiff who has been paid his salary or a pension during disability, or had his medical expenses or other losses paid for by another, or out of the proceeds of an accident or other insurance policy, may still recover full damages for these items from a defendant who is liable for the injury. To this extent, plaintiff may get double payment on account of the same items." (footnotes omitted)). 
rule is also widely applied to private insurance benefits in England, 106 many social security benefits are either partly or entirely deducted from the damage award. ${ }^{107}$ Similarly, damages in England are calculated after deduction of income tax. ${ }^{108}$ Nearly all American courts award damages based on gross pretax earnings. ${ }^{109}$ Finally, the usual American rule is that wages or salary paid by the einployer to an mjured plaintiff unable to work is a collateral benefit which does not reduce the damages; ${ }^{110}$ under the English rule such payments are deducted froin the plaintiff's damage recovery. ${ }^{111}$

\section{SOME Alternatives to TORT LAW}

The pursuit of tort claims by accident victims depends to some degree on whiat alternatives are available. English law seems to offer alternatives which are often easier to pursue and more attractive to the claimant than those likely to be available in America. ${ }^{112}$ Of course, it is not always easy to know whiat accident victims would actually prefer. It may be that litigation alternatives are pursued in England when tort suits would be filed in America, not so much because the English victim prefers a different outcome, but because inore obstacles lie $i m$ the way of a tort suit in England. But there are cases in which claimants seek other forms of satisfaction besides monetary damages. For example, unexpected hospital deaths often lead to litigation, not because the relatives want damages, but because they want explanations. A different course might be pursued if satisfactory information were made available. Accident victims whose mimediate financial costs are compensated-medical and basic wage losses-may decide that the cost of obtaining additional compensation outweighs the probable benefits. If, however, they were demied all immediate relief, they would be under greater pressure to pursue a tort clain. I will suggest that in England accident victims are inore likely to liave their basic losses taken care of, and are therefore less likely to pursue possible tort recoveries tlirough suit.

106. See Hussain v. New Taplow Paper Mills, Ltd., [1987] 1 All E.R. 417 (C.A. 1986) (proceeds of employer's insurance policy for payment of sick pay to injured workman deductible from damages in action against employer).

107. See P. AtiYah \& P. CANE, supra note 6, at 405-09.

108. See British Trans. Coinm. v. Gourley, [1956] A.C. 185, 210 (1955).

109. See 4 F. HARPER, F. JAMES \& O. GRAY, supra note 83, § 25.12 .

110. See Restatement (SECOND) OF TORTS § 920A(2) \& comment c(2) (1979).

111. Although this question has never been squarely answered in England, it has long been assumed to be the state of the law. See Metropolitan Police Dist. v. Croydon Corp., [1957] 2 Q.B. 154 (C.A. 1950); Parry v. Cleaver, [1970] A.C. 1 (1969).

112. It is also more difficult for the comparativist to study nonlitigious alternatives. While I am reasonably confident that I can compare tort law in England and the United States, I have to confess to a much scantier knowledge of alternative nontort remedies in America. 


\section{A. Medical and Hospital Costs.}

Unlike his American counterpart, the Enghish accident victim never has to worry about medical and hospital costs. Despite its many problems, the National Health Service remains committed to ensuring that everyone receives necessary medical and hospital treatment without charge. ${ }^{113}$ This is far different from the American situation. Although most Americans have some form of medical and hospital imsurance, significant numbers have none, and many of those who are insured have restricted or inadequate coverage.

\section{B. Basic Earnings Losses.}

It is today very difficult even to compare generally earnings losses across international boundaries. Social security and welfare prograins have become more and more coinplex, and fringe benefits in the form of sick pay or disability insurance are extensive but erratic in their coverage. I cannot pretend to offer any information on the modern position in the United States. There recently has been a major move in England toward the privatization of short-term sickness and disability payments. Legislation passed during Mrs. Thatcher's admimistration has obligated employers to pay "statutory sick pay" for the first twenty-eight weeks of disability, irrespective of the cause of disability. ${ }^{114}$ At the same time, the state has ceased to pay sickness and injury benefits to persons who are normally employed. ${ }^{115}$ Although the levels of statutory sick pay vary to a limited degree by income, they are low, and the maxima are reached on an income that is substantially below half the average industrial earnings. ${ }^{116}$ There are no increases for dependents and the payments are tax-

113. Despite this fact, however, claims for medical and hospital charges are still.made, and indeed constitute a major proportion of the largest tort claims. The reason for this is that private medicine still exists in the United Kingdom. The Law Reform (Personal Injuries) Act, 1948, 11 \& 12 Geo. 6, ch. 41, expressly provides that claims for medical and hospital fees arising out of a tort are not affected by the fact that the treatment could have been obtained froin the National Health Service frce of charge. For obvious reasons, private treatment is more likely to be sought in the posttrial (or settlement) periods.

114. Statutory sick pay was first introdueed by the Social Security and Housing Benefits Act, 1982, ch. 24, $\S 1-27$, (when it covered only the first 8 weeks of disability) and was extended by the Social Seeurity Act, 1985 , cl. $53, \S 18$, to cover the first 28 weeks of disability. Employers are entitled to be recouped by the state for the cost of these benefits, so they remain a form of Social Security rather than fringe benefits: the employers are used as an administrative agency by the state, largely because it was thouglit they could perform this function more efficiently than the state bodies, especially given the widespread existence of contractual fringe benefit schemes.

115. Long-term disability payments are, however, still inade by the state, where incapacity lasts for more than 13 weeks (for injuries received out of and in the course of employinent), and after 28 weeks in other cases. For a sketcli of the state benefit provisions, see P. ATIYAH \& P. CANE, supra note 6 , at 355-68.

116. Id. at 334 . 
able. These benefits, in other words, are far from generous, and anybody reduced to living on them would probably suffer a substantial loss of income.

Of course, the minimuin statutory requirements are exceeded by many employers under voluntary sick pay schemes, which have become far inore extensive in recent years. ${ }^{117}$ Few highly salaried earners in England today could expect to suffer a major decline in their incoine if they were unable to work because of sickness or injury for a period of a few weeks, and often up to six months; and although more prolonged and serious injuries might eventually lead to dismissal, a great many employers today incorporate soine sort of disability insurance in their schemes, thereby enabling a person who is permanently incapacitated to retire preinaturely on a full pension. ${ }^{118}$

At the same time, other developments in the private narkets have helped to mitigate the effect of short-term disabilities. During the past decade of high uneinployment, insurance for two of the most important mdividual financial commitments-home mortgage and consumer credit payinents-has becoine increasingly common. Although probably largely designed to protect against the very visible risks of unemployment, this insurance now often mcludes life and disability protections. Thus, a person injured in an accident today, and unable to work for some months, may well find that his home repayments and his bank loan (or other credit payments) on his car are covered by some form of insurance protection. It is at present impossible to give more precise data about this kind of insurance, or to quantify the amounts involved. But when we add this type of protection to the statutory and voluntary sickness and disability pay schenes, it is not unreasonable to conclude that most people in England probably do not today suffer significant net earnings losses for sliort-term disabilities up to six months in duration. ${ }^{119}$ Income protection programs of this kind are far from umiversal, and are no doubt restricted in many ways. But given the present hostility to inassive staterun welfare programs, they could well represent an important trend in the development of private alternatives to income protection.

Despite the gradual cutting down in the range and generosity of state welfare benefits in the United Kingdoin during the Thatcher admin-

117. Id. at $371-73$.

118. Id. at $372-73$.

119. Furthermore, we know that the overwhelming majority of accident victims are fully recovered within six months. See 2 PEARSON REPORT, supra note 16, at 12 table 5 (showing that only $1.6 \%$ of the injured are not fully recovered after six months). Of course, this is not to say that the seriously imjured and disabled are not without serious financial problems. They remain less generously treated by all welfare programs, as well as by the tort system. 
istration, it still seems that the proportion of accident victims who suffer significant financial deprivation is quite small. No doubt the losses of expectations-future earnings-are much greater, and still far more significant, but the propensity to sue may correlate more highly with financial deprivation than with losses of bare expectations. ${ }^{120}$

\section{No-Fault Benefits: Workers' Compensation and No-Fault Automobile Schemes.}

I turn now to two major areas im which American law seems to offer a higher level of nontort protection than the law im England. All American states have workers' compensation laws, and nearly half of them have auto no-fault laws. The United Kingdom has neither. It is true that there remain in the United Kingdom certain residual state benefits available only to those who have suffered mjury as the result of an accident arising out of and in the course of employment; to that extent the United Kingdom retaims a workers' compensation scheme. But separate legal provisions for such employment-related accidents have gradually disappeared since workers' compensation became part of the British welfare state in 1948. In recent years, the more generous benefits once available for industrial injuries liave gradually been lowered to the same rate for all categories of the sick and disabled. Furthermore, it seems clear that (at least under Conservative governments) this trend will continue, though in some cases it will be necessary to level-up the benefits currently available to injured workers only. In particular, long-term disability payments today are still much more generous for those injured at work than for the naturally or congemitally disabled. It is, however, beheved that the long-term government policy is to increase the disability benefits to the second group until they match those for people injured on the job. Eventually, it is expected that the "industrial preference"-that is the better treatment of those injured at work-will disappear, and with it, so will the last traces of the old workers' compensation system.

At the same time, injured workmen in the Urnted Kingdom, unlike their American counterparts, never gave up the right to sue their enployer in tort; indeed, the abolition of the fellow-servant rule in England greatly assisted the growth of litigation arising out of industrial acci-

120. Although this is no doubt speculative, some evidence for this proposition may be found in the (unexpected) discovery in the Oxford Socio-Legal Centre study that the propensity to sue in England actually varies inversely with socio-economic class, that is, less wealthy people are more likely to sue. See Genn, Who Claims Compensation: Factors Associated with Claiming and Obtaining Damages, in COMPENSATION AND SUPPORT, supra note 71 , at 53,63 . At least one possible explanation for this is that accident victims from higher social classes suffer less real financial deprivation (because of the existence of various benefits outlined in the text) even though they may suffer greater losses of expected future earnings. 
dents. ${ }^{121}$ As a result, by Englisl standards, litigation arising out of workers' injuries is relatively common, and, according to the Pearson Report, nearly lalf of all personal injury payments in 1973 coinpensated industrial injuries. ${ }^{122}$ All this may seem to run counter to the suggestion that the very weak propensity to claim in tort in England may be due to the availability of adequate state health and other benefits, which greatly reduce the levels of financial deprivation. The explanation for this may lie partly in the role of trade unions in relation to industrial accidents. One of the major services provided by British trade unions to their members has traditionally been legal and financial assistance in dealing with industrial accidents. ${ }^{123}$ Furthermore, the unions often have actively pursued such claims on belialf of their members, and lave even financed litigation without any risk to the member. ${ }^{124}$ To some extent, therefore, they behave more like American attorneys pursuing a tort claim, except that they do not deinand any proportion of the tort recoveries.

The general position in America is of course well known. Workers' compensation statutes generally bar any tort suit against the employer, though im recent decades injured workers have actively pursued tort claims against third parties. This is generally believed to be one of the major causes for the explosion of products hability claims, in that a high proportion of such claims are brought by workers injured by defective tools or working equipment, or by workers' compensation insurers pursuing subrogation riglits. ${ }^{125}$ This is an area, then, in which the law in the United States actually appears more hostile to tort claims and litigation than in the United Kingdom. It is not possible to measure the quantitative significance of this difference, or the degree to which it affects the overall finding that tort claims and payments are far higher in the United States than in the United Kingdom. Nor is it even possible to offer any rational explanation-as opposed to an historical explanation-of why this area seems to be singled out for such a different approach, bucking the general trend in both countries. ${ }^{126}$

121. P. ATIYAH \& P. CANE, supra note 6 , at 408 .

122. See 2 Pearson Report, supra note 16 , at 19 , table 11.

123. See Latta \& Lewis, Trade Union Legal Services, 12 BRIT. J. INDUS. REL. 56, 56-57 (1974) (surveying services provided); Genn, supra note 120, at 67-70 (describing influence of trade union activities on behalf of injured workers in prehgitation stages); Harris, supra note 71, at 119-20 (same).

124. This perhaps explains why a higher proportion of first offers of settlement is accepted in autonobile accident claims than in work-related accident claims. See Harris, supra note 71, at 101 table 3.6.

125. See, e.g., The California Citizens' Commission on Tort Reform, Righting the LIABILITY BALANCE 40-41 (1977).

126. A comparable area concerns accidental injuries suffered by military personnel. In both countries, such personnel will be entitled to state pension or disability payments. Tort hability of the 
The position with regard to road accidents is more confused. Here again, there is no overt no-fault scheme in the United Kingdom, though of course the health and welfare benefits of the modern state are available to all accident victims. In the Umited States, twenty-four states have nofault legislation conferring a range of benefits. ${ }^{127}$ Some, though not all, limit the right to sue in tort. ${ }^{128}$ Many of the states adopted the so-called "add-on" schemes, that is, schemes that do not limit the right to sue, but confer additional no-fault benefits on top of common law rights. ${ }^{129}$ Although there seems no doubt that schemes which actually limit the right to sue succeed in reducing the number of tort claims, ${ }^{130}$ it is controversial whether the add-on schemes also reduce the volume of litigation. On the one hand, some have argued that if the victim can promptly claim his no-fault benefits, he inay be less inclined to incur the liassle of pursing a tort claim even when he remains entitled to do so. On the other hand, it is argued that add-on schemes that do not restrict the right to sue are hardly likely to have any impact on tort claims. ${ }^{131}$ I have argued that in the United Kingdoin, the existence of a welfare state (and other measures), which limits the size of financial deprivation followimg an accident, is a inajor factor im keepmg down the volume of tort claims, even when such clainis could be brought. ${ }^{132}$ If this does not happen in the United States, the question must be whether it is due to cultural differences. That is, of course, perfectly plausible, but a simpler explanation is that the hassle of nuaking a tort claim im America is outweighed by the probable benefits. Beyond this, it is not possible to say whether there is proportionately less litigation arising out of workers' accidents in the United States than in Britain, and if not, which factors are chiefly responsible for outweighing the effect of the American no-fault conipensation schemes.

national government in both countries has been traditionally barred. See Feres v. United States, 340 U.S. 135 (1950); Crown Proceedings Act, 1947, 10 \& 11 Geo. 6, ch. 44, § 10. This section was repealed by the Crown Proceedings (Armed Forces) Act, 1987, ch. 25, so as to confer the right on military personnel to sue the Crown in tort. This is an illustration of the diversity of policies which operate in Britain in this area, the present government being more ideologically favorable to tort claims than many other governments of recent times, even though the general trend is still toward further development of nontort alternatives.

127. See 3 F. HARPER, F. JAMES \& O. GRAY, supra note $83, \S 13.8$, at 164 and supp. at 116 .

128. See id. $\S 13.8$, at 166 .

129. Id. $\$ 13.8$, at 165 .

130. See, e.g., the careful studies contained in Councll on LAW-RELATEd STudies, NoFault Automobile Insurance in Action: The Experience in MassachusetTs, Florida, Delaware aND Michigan (1977).

131. See, e.g., the exchanges reproduced in O'Connell, Operation of No-Fault Auto Laws: A Survey of Surveys, 56 NEB. L. REV. 23 n.47 (1977).

132. See supra notes $113-20$ and accompanying text. 


\section{Nontort Investigations and Adjudications.}

From these two areas, in one of which at least (workers' accidents) America may actually have a lower hitigation rate than Britain, I turn to examine a series of alternatives to tort law that probably reduce the propensity to sue in England. These alternatives can be broadly divided into two groups. ${ }^{133}$ The first group are alternative methods of inquiry and adjudication that do not necessarily involve the payment of compensation. The second group are alternative sources of compensation that may reduce the financial pressures to make a claim in tort. The two sets of alternatives are not entirely separable because some in the first group include relatively minor provisions for compensation. It is interesting that there is no alternative to tort law that sets out to perform both the compensatory and deterrent functions of tort law. Whether this indicates a greater specialization of function (and, perhaps, greater efficiency) is an interestimg question, though at present any answer is likely to be highly controversial. ${ }^{134}$

I start then with the nontort imvestigatory and adjudicative procedures. At the outset I must disclaim any pretense of pursuing the comparative method in detail. I simply do not know to what extent nontort alternatives are being developed in the United States, or even what pressures there may be for such alternatives. I can only record my general impression that tort law is still extensively perceived in the United States as an excellent investigatory procedure. When accidents occur, or disasters strike, those who want to know precisely what happened, and why it happened, appear to turn immediately to the courts for answers. ${ }^{135}$ It

133. There is, of course, a third group of alternatives to one of the functions allegedly performed by tort law, namely the regulatory laws and institutions, which atteinpt by direct measures to limit and control accident or injury levels. I do not attempt to deal with these in this article because it cannot seriously be suggested that significant numbers of tort suits are brought in order to regulate or control accident and injury levels, even if they indirectly perform this function. Hence, the existence of such alternatives to this function of tort law is unlikely to have more than a marginal effect on the tort claiun rate, unless and until a society determines that the preventive and regulatory function is better performed by other uneans, and therefore curtails the legal availability of tort claims, as New Zealand has done. See generally G. PALMER, COMPENSATION FOR INCAPACITY (1979) (analyzing tort, workers' compensation and social security reform in New Zealand and Australia).

134. It seems sensible to separate these two functions of tort law and deal with thein distinctly, because it is not obvious why the amount needed to deter potential tortfeasors should also be the appropriate suun to counpensate accident victiuns. Indeed, there are strong reasons for thinking the reverse. See Atiyah, A Legal Perspective on Recent Contributions to the Valuation of Life, in THE VALUE OF LIFE AND SAFETY 185, 188-92 (M. Jones-Lee ed. 1982).

135. The Challenger disaster seeuns to have been one of the few examples in recent times in which a public investigation (by a committce of the United States House of Representatives), rather than tort litigation, brought the facts to light. See HouSE COMM. ON SCIENCE AND TECHNOLOGY, Investigation of the Challenger Accident, H.R. ReP. No. 1016, 99th Cong., 2d Sess. 3 (1986). 
may well be that the self-financing aspects of American tort law are partly responsible for this tendency. The contingent fee means that people can find lawyers to bring their suits, and the willingness of juries to award substantial damages in cases where Enghish judges would not, means that lawyers, in turn, are willing to take such cases on a contingent fee. In England, many such cases probably fail to get into the tort groove because lawyers can only be found to take cases in which damages will be sufficiently large to cover the lawyer's fee; and although this works well enough in many ordinary cases of bodily injury, it may not work in many other situations, particularly when the cost of investigation is likely to be very high. On the other hand, the high damages awarded in many American tort cases inay be partly exphcable because the American jury can only express its indignation at the defendant's behavior, or its sympathy with the plaintiff, in one way-by awarding dainages. In England, many of the alternatives to tort law (like tort law itself ${ }^{33}$ ) are designed to produce a neutral and impartial set of detailed findings that can be published to the world. To some extent such publications express condemnation of the defendant's behavior; and when there is hittle or no actual financial loss as a result of that misbehavior, it is perhaps a better way (at least to a non-American) of proceeding than an award of enormous damages.

At all events, it seems clear that there is constant pressure in England to find and develop alternative sources of adjudication and investigation. Let me mention just a few of these. The first alternative, which is purely investigatory, is the public inquiry, conducted under a variety of statutes. ${ }^{137}$ The initiative for setting up such a Tribunal of Inquiry rests with the executive, but sometimes supportive resolutions are needed from the two Houses of Parliament. These inquiries are closely inodeled on ordinary adversary proceedings, but this obviously raises difficulties since judges sitting in adversary proceedings do not act on their own motion, but wait for soine party to initiate proceedings. In practice, Tribunals of Inquiry do not actually direct the investigations into the disasters they are called upon to examine. The investigation itself will be conducted by governinent officials, lawyers and (when necessary) police and other experts, acting under the general direction of the Tribunal. They take the initiative in calling the leading witnesses and directing the Tribunal's inquiries into the cliannels that have been found nost likely to reveal the causes of the disaster. Other parties inay also apply to call witnesses.

136. It must be remembered that in England, tort cases are tried by judges who make detailed findings of fact, a function an American jury does not perform. A judge can therefore express hisand the public's-indignation in words, rather than by piling on damages.

137. In particular, see the Tribunals of Inquiry (Evidence) Act, 1921, 11 Geo. 5, ch. 7. 
The Chairman of the Inquiry is almost invariably a senior judge; counsel appear in front of the Tribunal and examine and cross-examine the witnesses; eventually a report is issued, which reads very nuch like an opinion of an English judge giving his detailed findings based on the facts $\mathrm{n} 1 \mathrm{a}$ tort case. Of course there are differences, in that the report will also contain recommendations as to the future, and its findings on the conduct of the various parties involved will not be made in exclusively legal terms, but may also be couched in terms of "blameworthiness"138 or the like. Such inquiries are nearly always held in the case of mass disasters, where many people are killed or injured, such as major fires, explosions or otler natural disasters. Similar inquiries are also very common in the case of aircraft and railway crashes. Although these Tribunals of Inquiry have no power to award damages, their findings are likely to be so detailed that it is very unlikely that anyone would contest them. Once the report is published, tort claims are likely to be made on the basis of the findings wherever they appear warranted, and will almost certainly be quickly settled, subject to disputes on quantum.

These Tribunals of Inquiry are established to allay public anxieties about the causes of major accidents and disasters. It is felt that the pubhic is entitled to know what has caused such disasters in order that appropriate preventive measures can be taken, including if need be, changes in the law. They are not, therefore, designed primarily for the benefit of the victims of the disasters and their families; but in practice, they can be of enormous assistance to private tort claimants, in that the claimants are spared the massive cost of the investigations necessary to discover the causes of such disasters and to allocate responsibility for them. The victims of such mass disasters are, therefore, likely to stay their claim pending the findings of a Tribunal of Inquiry, though suits may sometimes be filed to avoid statute of limitations difficulties.

Next there are the Ombudsmen. An Ombudsman can be defined as a grievance commissioner with investigatory powers, and, on occasion, with power to award compensation as well. Ombudsmen first made their appearance in Britain im the field of public administration as a result of a perceived need for further protection against maladministration. This first Ombudsman - the Parliainentary Commissioner for Administration-is a statutory figure with statutory powers. ${ }^{139}$ His jurisdiction is much wider than English tort law, since he even deals with such matters as delays or discourtesy by government officials in dealing with members

138. See, for example, RePort OF THE TRIBUNAL APPOINTEd to INQUIRE INTO THE DISASTER AT ABERfaN, 1967 H.L. No. 316, H.C. No. 553, at 39, para. 77, which also gives details at paragraphs 5-14 on the working procedures of the Tribunal.

139. Parliamentary Commissioner Act, 1967, ch. 13. 
of the public. Unlike a judge, he has no formal powers to award compensation. The Ombudsman may not mvestigate complaints where the complainant has a perfectly good cause of action in law, unless he is satisfied that it would be unreasonable to expect the complainant to pursue the legal remedy. ${ }^{140}$ Thus, the Ombudsman's jurisdiction is actually based on a cultural component, and the less the propensity to sue is valued, the more extensive the Ombudsinan's jurisdiction will become. In modern English practice, the Parhamentary Commissioner, like most Ombudsmen, operates much less publicly than Tribunals of Inquiry. He does not usually hold oral hearings, but investigates complaints privately, usually by demanding production of papers and making written inquiries. The Ombudsmen are nore mvestigatory in function than Tribunals, which (as we have seen) work in a semi-adversarial procedure. Furthermore, unlike courts and Tribunals of Inquiry, the Ombudsman has his own permanent staff of officials who work under his direction. Thus, once the complainant has made his written complaint to an Ombudsman, there may be little more for him to do, though he may later have an opportunity of replying to any answers made by the respondents to the complaint. Because the Ombudsman's published findings are laid before Parliament, they carry considerable moral force. Further, he sometimes recommends that financial losses caused by maladmimistration be replaced by the relevant government department on an ex gratia basis. Typical cases concern quantiffable financial losses due to imcorrect advice given by a government department. ${ }^{141}$ The Ombudsman, however, is imclined to leave complainants to their legal remedies in the court where they seek compensation for nonpecumary losses, because of mental distress or defamation. ${ }^{142}$

In addition to these national Ombudsmen, the Local Government Act of $1974^{143}$ established three local government Ombudsmen for England and one for Wales. These Ombudsmen are given broad powers to handle complaints of maladministration by local authorities. ${ }^{144}$ Like the national Ombudsmen, these local Ombudsmen handle inany complaints which might otherwise have become tort claims. Although they have no power to award compensation, they can inake findings of wrongdoing and recommend to the relevant local authority soine ex gratia payinent. They may also make further reports if their findings are rejected by the local authority. Many people find this procedure both cuinbersome and

140. Id. § $5(2)$.

141. See The Commissioner's SeCond RePort For 1985-86, H.C. No. 275, ch. 1, at 3-10.

142. See id. at 47.

143. Local Government Act, 1974, ch. 7.

144. See, e.g., The Local OMBUdSMen, Report for Year Ended March 31, 1986. 
ineffectual because it ultimately leaves local authorities to judge their own cause. On more than one occasion local authorities have simply ignored the findings by the local Ombudsmen. There is, therefore, pressure to make the local Ombudsman's findings legally enforceable; but even as currently used, they do offer an alternative to proceedings in tort in certain cases. ${ }^{145}$

Another Ombudsman, whose jurisdiction overlaps significantly with tort law, is the Health Service Commissioner. This Ombudsinan is limited in his authority; he can imvestigate claims with a remedy in law, in cases where he thinks it reasonable for the complainant not to sue. ${ }^{146}$ His principal field of investigation relates to failures of service im the National Health Service hospitals and extends to many cases which could easily form the basis of inalpractice actions. Because many cases within his jurisdiction could also be brought as tort actions, the Health Ombudsman generally conditions his mvolvement im the investigation upon the express waiver by the complainant of any claims to sue. Although adversary-minded tort lawyers may find this requirement outrageous, the claim waiver requirement is justified by the purpose of the investigation: in cases of sudden or unexpected death, or death due to medical mistreatment, the relatives often want explanations rather than compensation (which in fatal cases may not even be recoverable in tort). ${ }^{147}$ These explanations, however, are seldoin forthcoming froin hospital staffs reluctant to disclose information which ultimately might be used against them in a malpractice suit. Thus, this pohicy seems to be justified by the results, in that many complainants are willing to waive their legal claims in exchange for a detailed and thorough investigation by the Health Ombudsman. Indeed, he sometimes holds oral hearings, especially in cases imvolving conflicting evidence. The Ombudsman's published reports are minutely detailed and every bit as thorough as a High Court decision. ${ }^{148}$

The work of the Health Ombudsman suggests that tort law has its own built-in Catch-22: individuals who refuse to observe the decent courtesies of hife and disclose potentially embarrassing infornation for fear of suit often find themselves in court-and subsequently hable for

145. For instance, a case referred to in the 1986 Report, supra note 144 , in which a local authority stripped the tiles off the coinplainant's roof, overlooking the fact that he had actually bought his house from thein (that is, they no longer owned the house), and then refused to answer his solicitors' letters. Id. at para. 20; see also id. at para. 76 (death of child while in local authority's care).

146. National Health Service Act, 1977 , ch. $49, \S 116$ (1natters not subject to investigation).

147. P. ATIYAh \& P. CANe, supra note 6, at 76-80.

148. See, e.g., HeAlth Service CoMmissioner, SECOND RePort For Session 1980-81, Case No. 450 , at $24-35$ (a very bad case which would certainly have founded a tort claim if it had not been for the waiver). 
huge damages-precisely because they have failed to cooperate in the first place. Because the existence of tort law and the threat of hitigation often prevents the disclosure of information (which is often all that is sought), a tort suit becomes a kind of "freedoin of information" action for those wishing only to find out what actually happened. This, I think, is borne out by study of many of the cases examined by the Health Ombudsman. Many begin with soine relatively trivial discourtesy to either a hospital patient or relative of the patient, linked with soine inedically related trauma suffered by the patient. In the absence of inore information as to what has actually happened, these incidents easily can be attributed to medical or hospital neghigence. These discourtesies, which then tend to result in a coinplaint, are usually cleared up by private examination by the Ombudsman. The result is often a handsoine apology, as well as subsequent steps to avoid repetition of the events. One does not have to use inuch imagination to appreciate the likely result in the absence of these investigatory processes. The minor courtesy of disclosure is denied; hitigation ensues in which unjustified allegations are inade about the actual treatment of patients and any resultant mishaps or deaths. After inonths or even years of delay, during which the hitigants become more and inore indignant and obdurate, a trial is held im which sores are opened and terrible allegations are inade public. Public indignation and syinpathy are multiphed, and huge damages are awarded for something which only dubiously was the result of inedical neghigence.

The relative success of the Oinbudsmen inay partly explain the recent public demand for greater regulation and control by various professional bodies over their own members. In the past, self-regnlation over professional misconduct was largely confined to the inost serious violations, such as fraud by solicitors and other lawyers, or scandalous and gross medical inalpractice. In recent years, many professional bodies have come under heavy public pressure to exercise greater control over less outrageous professional misconduct, such as neghigence and incoinpetence. Many British professional bodies have statutory disciplinary powers over their own inembers; their proper exercise is seen by Parliament and the public as some sort of a quid pro quo for the monopoly privileges that the profession enjoys. The professions are, therefore, very sensitive to public complaints over their failures to exercise disciplinary control.

Solicitors have been particularly hard hit by the increasing public pressure upon the professions. The Law Society, a statutory body that exercises control over the solicitors branch of the English legal profession, has had disciplinary powers over its members for many years. A first attempt to alleviate public anxiety over the failure of the profession 
to exercise adequate control over its own members came in 1974 when the Lord Chancellor was empowered to appoint a Lay Observer to supervise the Law Society's use of its disciplinary powers. ${ }^{149}$ Although the Lay Observer annually reports to the Lord Chancellor, it soon became clear that he had no real power to do anything about complaints of professional neghigence. ${ }^{150}$ The Law Society simply declined to adjudicate complaints of mere negligence against solicitors, perhaps out of fear that their mvestigations would result in civil suits and expanding legal hability. In the 1980s, however, the Law Society was rocked to its foundations by a complaint of gross overcharging against a member of its own governing body. ${ }^{151}$ The complaint, rejected by the Law Society, was brought before the High Court, where very serious charges were either adinitted or proven. The solicitor was eventually struck off the roll (that is, disqualified from practice) by the Court. After a Committee of Inquiry described the Law Society's handling of the whole episode as a "disgrace to the Law Society," 152 and following an exhaustive study of the Law Society's disciplinary procedures, ${ }^{153}$ new statutory provisions were enacted. 154

Today, the Law Society has a Solicitors' Disciplinary Tribunal, which is serviced by a Complaints Bureau. The Complaints Bureau conducts the investigations and, when necessary, presents a case before the Tribunal. Furtliermore, these bodies are now explicitly einpowered to investigate allegations of neghigence and imcompetence. In addition, the Tribunal may to some extent police attorney fees. Although it cannot award damages at large, the Tribunal can disallow claims for fees for incompetent work. This power extends beyond legal hability in that the Tribunal could, for instance, deny coinpensation for dilatory professional services even when no financial loss has been caused. It can also require unsatisfactory work to be rectified at the solicitor's own expense. As with the various Ombudsinen, the new statutory provisions prevent the Law Society from exercising disciplinary powers im cases where the coinplainant has a legal remedy that he could "reasonably" have been ex-

149. Solicitors Act, 1974, ch. $47, \S 45$. The Act also provided that the Solicitors' Disciplinary Tribunal contain some lay members. Id. at $\S 46(3)$.

150. See, e.g., The Tenth ANNUAL Report OF THE LAY ObSERVER, 1985, H.C. No. 387, at 34 para. 8.

151. The full story is detailed in the Report of the Committee of Enquiry, published as a supplement to 81 LAW SocIETY's GAZETTE 474 (1984).

152. Id., supp. at para. 43.

153. See Enquiry by Coopers \& Lybrand Management Consultants, 83 LAW SocIETY's GAZETTE 580 (1986).

154. See Administration of Justice Act, 1985, ch. 61, $§ 1$ (amending Solicitors Act, 1974, ch. 47, $\S 44 \mathrm{~A})$. 
pected to exercise. ${ }^{155}$

It remains to be seen to what degree other professions will be able to provide a comparable system of public redress for negligence and incompetence. The Bar insists that its Code of Professional Practice requires every practicing barrister to be "competent in his professional activities," but solicitors regularly complain that the Bar never disciplines barristers for incompetence. ${ }^{156}$ The medical profession is still restricted to disciplinary control over "serious professional misconduct," which may not extend to matters of carelessness, rudeness, bad timekeeping, overcharging and so on. ${ }^{157}$ The disciplinary body for the medical profession, the General Medical Council, receives many sucli complaints; althougli currently regarded as outside its statutory jurisdiction, the President of the Council has publicly questioned whetlier its powers slould not now be expanded to deal with these complaints. ${ }^{158}$ Members of the public, lowever, have alternative channels of conıplaint witl respect to allegations against the National Health Service doctors. Although these doctors are employed under contracts witl the Departinent of Healtll, they nominally enjoy "independent contractor" status, and are not treated as government employees. Complaints can be inade about their professional beliavior to one of the statutory bodies, called Family Practitioners' Committees, which have various disciplinary powers, such as the power to recoinmend the Department of Health to deduct sums due to thein by way of remuneration. 159

Another body which offers some alternative investigatory procedures to tort law is the new Police Coinplaints Authority, established by statute in 1984.160 As with the solicitors, there has been a long history of trial and error with regard to imvestigations of public coinplaints against the police. The main problem is finding an appropriate body to carry out the investigations. This difficulty is alleviated by the absence of a British national police force. The police in the United Kingdom are local bodies,

155. Id. at $\S 44 \mathrm{~A}(3)(\mathrm{a})$.

156. See, e.g., Disciplining Inefficiency, 137 NEw L.J. 68 (1987).

157. See The Independent (London), Jan. 30, 1987, at 3.

158. Id. Since 1984 the General Medical Council (GMC) has taken cognizance of behavior which is "incompetent, inconsiderate and unacceptable or obvious misconduct," id., but it still insists that it is only concerned with serious or gross misconduct. See GMC Strengthens Professional Conduct Procedure, 289 BRIT. MED. J. 1325, 1326 (1984).

159. The most serious allegations go to a National Health Service Tribunal, which has power to disqualify a practitioner from working under the Health Service altogether. See National Health Service Act, 1977, ch. 49, §46. Consumers' organizations complain that the procedure before these disciplinary bodies is weighed against the complainant who is not allowed to appear by counsel or solicitor, whereas, the doctor is. These nontort alternatives are fully explored in S. Chopin, supra note 56, at ch. V (though there have been changes since this thesis was written).

160. Police and Criminal Evidence Act, 1984, ch. 60, §§ 83-105. 
under the control of Chief Constables and local Police Authorities, though subject to some national supervision by national officers, such as the Chief Inspector of Constabulary and, ultimately, the Home Secretary. ${ }^{161}$ It is therefore possible to call in officers from one police force to investigate allegations against members of another. Of course such an investigation, without any supervision, would be unsatisfactory because of the natural public suspicion that the police would tend to cover up the misdeeds of their own colleagues. The new statutory sclieme adopted in 1984 attempts to overcome this difficulty by creating an independent body known as the Police Complaints Authority, whicll supervises the investigation of complaints. This means that the investigatory officers have to be selected with the approval of the Authority, which closely momitors their investigation. They exercise some general control over the way an investigation is conducted (including even sitting in when witnesses are interviewed), read the imvestigators' reports and statements taken from witnesses, and where appropriate, refer the case to the public prosecutor to consider wliether crimmal charges are appropriate. They can also direct that disciplinary proceedings be taken against a police officer. In serious cases, when allegations are likely to be made (such as when an innocent meinber of the public is shot by police in the course of their duties), a member of the Authority is likely to take charge of an investigation almost immediately. The Authority also has power to recommend changes im police practice and procedure to local police autliorities; in their first year they obtained various changes relating to the use of police dogs, police cell procedure and the marking of police cars. ${ }^{162}$

This is a new body, and it is not yet clear how successful it will be in convincing the public that it is capable of remaining truly independent and exercising adequate control over the police. It is also not yet clear how far it can offer a satisfactory alternative to tort proceedings. It has no power to award compensation, or direct the payment of compensation, though its published findings will in some cases almost certainly form the basis of tort claims. It will never wholly replace the need for possible tort claims, because in the absence of oral hearings, the Authority lias no real ability to make findings against police officers where the facts are seriously in dispute, especially when the only available evidence coines from the officers themselves. In sucli cases the Authority may find itself faced with two flatly imconsistent accounts, and it will often be unable to resolve the conflict. On tlie other hand, the Autliority's imvestigatory process moves at a speed which can never be matclied by tort

161. See Police Act, 1964, ch. 48 , as subsequeutly amended.

162. See First ANNuAl RePort of the Police Complaints AUthority 1985 H.M.S.O., 1986. 
claims, ${ }^{163}$ and should often be able to offer an investigatory service superior to anything the ordinary tort claimant can get from his lawyer.

Most of the alternatives to tort law so far reviewed are primarily investigatory, and are therefore deterrent, rather than coinpensatory in purpose. One of the main sets of alternatives to tort today, which is designed to be compensatory, is the increasing provision for victims of crime. Two main sets of procedures are currently at work. The first, which deals mainly with relatively minor cases, gives the criminal courts powers to order that compensation be paid by an offender when soineone has suffered loss or injury as a result of his crime. ${ }^{164}$ Very large numbers of such compensation orders are made today by criminal courts, ${ }^{165}$ though it is often complained that courts are inuch more willing to inake compensation orders in cases involving property damage rather than personal injury. ${ }^{166}$ The difficulty seems to be that criminal courts are inexperienced in fixing damages for nonpecuniary losses, and feel much more confident about making compensation orders when some evidence is given as to the value of damaged or destroyed property. Recently, some regions have experimented with simple tariffs to guide criminal courts in compensating victims in minor personal injury cases; these have been found quite successful. ${ }^{167}$ There are also wider proposals for enabling criminal courts to make further coinpensation orders. ${ }^{168}$

The second set of provisions provides a more substantial nontort remedy for serious cases of personal mjury. Since its creation in 1964, the Criminal Injuries Compensation Board has provided substantial compensation for those mjured as a result of criminal violence. ${ }^{169}$ The Board operates under a scheine approved by Parhanient (though it has

163. For example, on January 1, 1987, a black youth of 19 was arrested and a few days later taken to the hospital with severe injuries which required brain surgery and left him partially paralyzed. His father complained that whon he inquired of the police where his son was, he was refused all information, and only discovered his whereabouts after his son had been admitted to the hospital and operated upon. By January 22, the case was under investigation by the Pohice Complaints Authority. See The Independent (London), Jan. 23, 1987, at 2.

164. Powers of Criminal Courts Act, 1973, ch. 62, \& 35. In England, the term "compensation," which in American usage often implies state-paid compensation, extends to compensation paid by the offender himself. In America, compensation paid by the offender is called "reparation."

165. See 16 Social TRENDS, supra note 21, at 197 (119,000 compeusation orders made by magistrates' courts in 1984 and 6000 made by the Crown Court).

166. Vennard, Magistrates' Assessments of Compensation For Injury, 1979 CRIM. L. REv. 510, 510.

167. Id. at 511-13.

168. See generally D. Hodgson, The Profits of Crime AND Their Recovery (1984); Ashworth, Punishment and Compensation: Victims, Offenders and the State, 6 Ox. J. L. STUD. 86 (1986).

169. For a summary of the scheme, see P. ATIYAH \& P. CANE, supra note 6, at 291-312; see also Reports of the Criminal InJuRies Compensation BoARd, cited in P. ATIYAH \& P. CANe, supra note 6, at xxii; D. MIERS, RESPONSES TO VICTIMIZATION (1978). 
not yet been put imto statutory form $)^{170}$ and is funded by public monies. In essence, and subject to some qualifications, the Board pays compensation on the same primciples and at the same general levels as damages at common law, including sums for pain and suffering and loss of amenity. Because tort damages in England are assessed by judges and not juries, there is no particular difficulty in having comparable levels assessed by a Board of qualified lawyers. ${ }^{171}$ There are several important differences between the awards made by the Board and the courts: the schenie establishes a threshold, at present of $£ 400$ (roughly $\$ 700$ ), below which compensation is not payable, as well as a fairly high ceiling for loss of earnings (presently about $£ 30,000$ or $\$ 52,500$ per annum); although the Board does not award punitive damages, compensation is payable even when the imjury was caused by someone not responsible im tort because of insanity or infancy; the collateral benefits rule does not operate with regard to any other benefits payable out of public funds; finally, there is a rather wide exclusion from compensation of those whose conduct or way of life makes their compensation out of public funds mappropriate. ${ }^{172}$ Despite the exclusions, the sclieme is in many respects very generousfar more generous than comparable American schenies ${ }^{173}$-and it replaces a considerable anount of potential tort litigation. Although not many tort actions are brought against violent criminals tlieniselves, there are of course many tort claims, both in England and America, which arise out of criminal violence. Furthernore, because many of these possible tort claims are likely to be brouglit against third parties ratlier than the criminals theniselves, they often present especially difficult questions of responsibility, and are likely to be appealed. ${ }^{174}$ Thus, the existence of

170. The scheine was in the process of being put into statutory form as part of the Criminal Justice Bill in 1987, when the dissolution of Parhament led to its abandonment for the time being.

171. There has been difficulty with certain cases, such as rape, in which tort claims are very rarely brought in England, since there is little experience for the Board to rely on. In the extraordinary case of W. v. Meah, damages in tort of $£ 10,250$ (roughly $\$ 17,940$ ) were awarded agamst a rapist after the victim had been awarded $£ 3600$ (roughly $\$ 6300$ ) by the Criminal Injuries Board, [1986] 1 All E.R. 935, 942 (1985). Awards from the board inust be repaid out of the damages recovered from the attacker. The damages in Meah would certainly have been vastly higher if assessed by an American jury-perhaps a hundred times higher.

172. For a discussion of these exclusions, see P. Atryah \& P. CANE, supra note 6, at 306-08.

173. For a snmmary of solne American schennes (which it must be said are stingy by coinparison with the English provisions), see Hoelzel, A Survey of 27 Victim Compensation Programs, 63 JudICATURE 485 (1980).

174. Among the inany sorts of cases falling within the scheine are claims that could be brought in tort against doctors or psychiatrists for failing to warn of the homicidal threats of a patient, see, e.g., Tarasoff v. Regents of Univ. of Cal., 17 Cal. 3d 425, 551 P.2d 334, 131 Cal. Rptr. 14 (1976), or against other public officials for similar failings, see, e.g., Johnson v. California, 69 Cal. 2d 782, 447 P.2d 352, 73 Cal. Rptr. 240 (1968), claims against the pohice for failure to protect a plaintiff, see many examples cited in M. SHAPO, THE DUTY TO ACT 98-134 (1977), and claims against railroads, 
this scheme, which enables compensation to be claimed more cheaply and more easily than by litigation, undoubtedly serves to eliminate many possible tort claims.

\section{SOME CONCLUSIONS}

This rapid survey of some of the alternatives to tort law in England does not profess to be compreliensive. There are in fact many other areas where alternatives are coming into existence, or becoming more widely used. Some are primarily deterrent im nature, others are compensatory im purpose, some simply offer a different procedure to adjudicate claims that could be brought in tort. In some cases the alternatives replace claims which are perhaps more likely to be brouglit im contract but which could also be brought in tort. For example, the Press Council, ${ }^{175}$ altlough lacking power to impose sanctions, offers the possibility of a condemnatory ruling as an alternative to a suit for defamation or one for breach of confidentiality or infringement of privacy (the last of which is not a tort in English law). There are as well new Ombudsinen appearing in the private market, such as the Banking Ombudsinan and the Insurance Oinbudsinan, botli of whom liave power to award quite substantial compensation in a dispute between a customer and a bank or insurer. In addition, the Control of Pollution Act of 1974 enables the citizen to obtain an order for the abatenent of a noise nuisance througl an administrative body (a local authority ${ }^{176}$ ). Some of these local authorities liave delegated their powers to a single person who can, when appropriate, Inake an immediate order to stop a noise nuisance in the middle of the night-something which would hardly be possible for a court to do. Finally, any serious coinparative study would reveal that England has procedures for dealing with certain abuses of legal process typically redressed in America by tort actions, even though Englisl procedures would not be perceived as being alternatives to tort. For instance, the control of court procedures by orders for costs (including attorney's fees), or for prejudgment interest, or sinply by preventing the abuse of ordinary court procedures, seeins more widely practiced in England than in America, where new tort liabilities for abuses of process, or even for failure to pay debt by insurance compamies, have been invented or

hotels and other institutions for failure to protect inmates, see 3 F. HARPER, F. JAMES \& O. GRAY, supra note $83, \S 16.5$, at 413 n.63.

175. See N. Paul, Principles for The Press, A Digest of Press Council Decisions, 1953-1984 (1985). The Press Council has had some very distinguished Chairmen, such as Lord Devlin, Lord Pearce and (currently) Sir Zelınan Cowen, but it has not been very effective. For a highly critical view, see G. Robertson, People Against the Press (1983).

176. Control of Pollution Act, 1974, ch. 40, $\S \S 58-59$. 
developed. ${ }^{177}$

Is it now possible to draw any general conclusions from this survey? I think it is possible to make two tentative suggestions. The first is that tort hitigation, particularly in the higher courts, appears to me to be regarded in England as something fundamentally out of the ordinary. Litigation, and especially High Court litigation, is, I think, clearly regarded as a way of control and of securing compensation that is not, and ought not to be, regarded as a routine, everyday procedure. This is, I think, well demonstrated by the regular recurrence of the formula in modern nontort alternative procedures that the alternative is to be open to citizens when it would not be "reasonable" for that claim to be brought in the courts. What can be sensed from the use and workings of this formula is the idea, not merely that relatively trivial cases should not be hitigated, but that litigation itself is often, indeed very often, unreasonable. The alternatives seem to be favorably regarded particularly when the claimant is not claiming substantial compensation, or is only claiming for quantifiable economic losses, and is not asking for compensation for paim and suffering. In a great many areas the first and most obvious means of obtaining compensation, or of controlling some perceived abuse, lies outside the courts. But equally it remams true that the courts often continue $\mathrm{m}$ the background to be available for inajor issues of principles, or for really new and big cases. Historically, this falls into line witl the traditional use of the court system in England. Courts lave never been regarded as imstruments for everyday use in England. They are too slow, too expensive, too cumbersome and too alien to the man in the street. They are far more effective when they are used as instruments of supervision, called on only for occasional use. My sense is that this is less true in America, where tort claims are, in many areas, thought of as the primary means of redress of grievances, rather than as rare and cumbersome weapons to be wheeled out for occasional use only.

The second tentative conclusion that can be drawn from this article is that tort law, as a general medium of legal control of standards of behavior, plays a much more important role in America than in England.

177. American developments involving the creation or expansion of tort liability in circumstances in which English law proceeds by more direct control of abuse of process, are illustrated by RESTATEMENT (SECOND) OF TORTS $\$ \S 674,682$ (1977) (wrongful use of civil proceedings; abuse of process). Compare O'Toole v. Franklin, 279 Or. 513, 569 P.2d 561 (1977) (discussing in context of malicious prosecution the "English Rule" of special injury and the more expansive "American Rule" as it appears in RESTATEMENT (SECOND) OF TORTS $\$ 674$ (1977)); Scliwarzer, Sanctions Under the New Federal Rule II-A Closer Look, 104 F.R.D. 181 (1985) (discussing increased sanctions provided for in the 1983 amendment to Rule 11 of the Federal Rules of Civil Procedure) with Business Computers 1nt'l, Ltd. v. Registrar of Companies, [1987] 3 All E.R. 465 (control of litigation by court leld a ground for declining to extend liability for negligent conduct of litigation). 
Nobody in England would regard tort law as playing more than a very peripheral role im the life of the society, as having any major responsibility for setting social standards of behavior, or as policing and controlling the operation of the free market. That is clearly not the case im the United States. Because of the power of juries, the very large awards of damages in America as compared witl the ratlier miniscule awards im England, and because so many areas of public life and activity are controlled by the courts in America (as opposed to being regulated by the legislature or the government, as they are im England ${ }^{178}$ ), tort law is a more central part of the means of social control in America. Together with the free market, tort law thus plays in America very mucli the role set for it by liberal theorists wlio wisli to minimize the collective role of the state and the legislatures. Or at least it would do so, if it were not for the paradoxical fact that so much modern American tort law lias fallen under the control of a sort of proplaintiff party which seems to see its function as performing the redistributive exercises performed by legislatures in other deinocratic systens. That is why American tort law is in crisis; but that is another story. ${ }^{179}$

178. See P. ATIYAH \& R. Summers, supra note 72, at 115-56.

179. See Atiyah, American Tort Law in Crisis, 7 Ox. J. LEg. Stud. 279 (1987). 